Boise State University

ScholarWorks

Civil Engineering Faculty Publications and

Presentations

Department of Civil Engineering

4-1-2012

\title{
Impacts of Climate Change on Hydrology and Water Resources in the Boise and Spokane River Basins
}

\author{
Xin Jin \\ Boise State University \\ Venkataramana Sridhar \\ Boise State University
}




\title{
Impacts of Climate Change on Hydrology and Water Resources in the Boise and Spokane River Basins
}

\author{
Xin Jin and Venkataramana Sridhar \\ Boise State University
}

\begin{abstract}
In the Pacific Northwest, warming climate has resulted in a lengthened growing season, declining snowpack, and earlier timing of spring runoff. This study characterizes the impact of climate change in two basins in Idaho, the Spokane River and the Boise River Basins. We simulated the basin scale hydrology by coupling the downscaled precipitation and temperature outputs from a suite of global climate models and the Soil Water Assessment Tool (SWAT), between 2010 and 2060 and assess the impacts of climate change on water resources in the region. Precipitation and Temperature projections between 2010 and 2060 exhibited a wide range. For the Boise River basin, changes in precipitation ranged between $-3.8 \%$ and $36 \%$. Changes in temperature were expected to be between 0.02 and $3.9{ }^{\circ} \mathrm{C}$. In the Spokane River region, changes in precipitation were expected to be between $-6.7 \%$ and $17.9 \%$. Changes in temperature appeared ranging between 0.1 and $3.5{ }^{\circ} \mathrm{C}$ over a period of next five decades between 2010 and 2060. In the Boise River basin, change in peak flows (March through June) were projected to range between -58 to $+106 \mathrm{~m}^{3} / \mathrm{s}$ and for the Spokane River basin the range was expected to be between $-198 \mathrm{~m}^{3} / \mathrm{s}$ and $+88 \mathrm{~m}^{3} / \mathrm{s}$. Both the basins exhibited substantial variability in precipitation, evapotranspiration and recharge estimates. A range of possible hydrologic impacts at a local scale was expected to enable the stakeholders with possible options in their decision-making process.
\end{abstract}

Keywords: hydrology, streamflows, climate change, SWAT

\section{Introduction}

In general, climate in the Pacific Northwest of U.S is changing. Mote (2003) indicates that annual average temperatures in the Northwest rose faster than the global average during the $20^{\text {th }}$ century. Temperatures in the Northwest had risen $0.8^{\circ} \mathrm{C}$ in comparison to the global increase of $0.6^{\circ} \mathrm{C}$ (Folland et al., 2001). This warming occurred mostly during the winter and spring. The predominance of winter and spring warming, especially in regard to extreme minimum temperatures, was confirmed more recently in a smaller study at two locations: one in Western Montana and the other in British Columbia (Caprio et al., 2009). Lengthened growing season (Kunkel et al., 2004), decline of snowpack (Mote, 2006), and earlier snowmelt and spring peak flows (Stewart et al., 2005; Hamlet and Lettenmaier, 1999) in the region have been widely reported. Water supply in the West is vulnerable to climatic change, mainly because it relies heavily upon the capture of the spring runoff. Warmer temperatures are likely to alter the rain and snow distributions causing an increase in the wintertime streamflow and shifting peak flows in the spring as well as causing the snowpack to retreat to higher elevations (Hamlet and Lettenmaier, 1999).

The Pacific Northwest is expected to have increases in annual temperature of about $1.1^{\circ} \mathrm{C}\left(2.0^{\circ} \mathrm{F}\right)$ by the $2020 \mathrm{~s}$, $1.8^{\circ} \mathrm{C}\left(3.2^{\circ} \mathrm{F}\right)$ by the $2040 \mathrm{~s}$, and $3.0^{\circ} \mathrm{C}\left(5.3^{\circ} \mathrm{F}\right)$ by the $2080 \mathrm{~s}$, compared with the average from 1970 to 1999 , averaged over the climate models (Mote and Salathe, 2009). In case of projected precipitation, modest changes $(+1$ to $+2 \%$ ) are expected with an increased winter precipitation and decreased summer precipitation. It is possible that an increase in future precipitation, which some Global Climate Models (GCMs) predict (Mote and Salathe, 2009), could offset the impacts of warming temperatures and it could have direct implication on the regional water supply. However, it should be noted that a $13 \%-38 \%$ increase in precipitation during the $20^{\text {th }}$ century (Mote, 2003) did not reverse observed impacts of warmer climate in the trend analysis studies mentioned earlier (Kunkel et al., 2004; Mote, 2006; Stewart et al., 2005). These studies indicated that historic climatic change in the Northwest is not likely due to only natural fluctuation of climate caused by the El Niño-Southern Oscillation (ENSO) and the Pacific Decadal Oscillation (PDO) which are thought to govern natural climate variability in the Northwest. More recent studies using the detection and attribution (D-A) analysis have linked the change in growing season (Christidis et al., 2007), decline in snowpack (Pierce et al., 2008), and earlier spring runoff (Barnett et al., 2008; Hidalgo et al., 2009) 
to anthropogenic factors (i.e., greenhouse gas emissions). A similar D-A analysis on all three variables by Barnett et al. (2008) found that $60 \%$ of the change in hydrology in the West over the last half century is the result of human induced-climate change.

How will climate change impact water resource management in the Pacific Northwest, in particular the Boise River and Spokane River basins? In order to understand the effects of climate change on regional hydrology, it is necessary to first downscale the climate model-generated precipitation and temperature and drive the hydrology model with these outputs to quantify the hydrological impacts. There have been some studies conducted over the Pacific Northwest and these analyses provided limited understanding on the expected change on a decadal basis in the Boise River and Spokane River basins. Also, regional hydrologic studies have shown that a strong surfaceground water interaction exists in the Spokane River basin and the contribution of flow from Spokane ValleyRathdrum Prairie as return flow to the Spokane and Little Spokane Rivers during critical low flow periods (Hseih et al., 2007; Barber et al., 2009). Furthermore, Hseih et al. (2007) also found that future summer groundwater withdrawals would adversely decrease the return flows in the Spokane River and the Little Spokane River. Alternately, low flows in the Spokane Valley-Rathdrum Prairie region were somewhat enhanced by augmenting infiltration basins and injection wells with winter surface water diversions (Barber et al., 2009). Climate change impacts via hydrological water balance assessment would therefore provide a basis for the region's water resources availability under current and future climate conditions. Our objective of this study is to simulate the future hydrology and water resources of the Boise River and Spokane River basins using the climate model projections and more specifically our approach includes the methods 1) to downscale the climate model outputs and understand the future trends in precipitation and temperature for a suite of climate models 2) to quantify the timing and magnitude of peak flows and low flows by deriving the basin hydrologic parameters with a thorough calibration 3) to analyze and evaluate the hydrological components by decade for both the basins.

\section{Climate Model Downscaling}

Forcing factors of GCMs are greenhouse gases and sulfate aerosols (which reflect sunlight and also promote cloud formation, thereby offsetting greenhouse gases locally) (Mote and Salathe, 2009). These forcing factors along with socioeconomic changes are highlighted by three scenarios based on the emissions, B1 (550 ppm), A1B (750 ppm), and A2 (does not stabilize). The trends in temperature and precipitation captured by the model reflecting the historic conditions were given priority by numerous studies as the indicator of reliability in predicting the future conditions. Our review of literature on climate models resulted in choosing five climate models, namely, MIROC 3.2, CCSM3, IPSL, HadCM3 and PCM for implementing them in our hydrological impact studies and they are shown in Table 1. The outputs, primarily precipitation and temperature, from the GCMs are coarser and they needed to be first downscaled to a specific area if we were to get meaningful interpretation of the impacts of climate change at the local scale. The original climate projections are from the World Climate Research Programme's (WCRP's) Coupled Model Intercomparison Project phase 3 (CMIP3) multi-model dataset, which was referenced in the Intergovernmental Panel on Climate Change Fourth Assessment Report. As the first step we have downloaded biascorrected and spatially downscaled climate projections derived from CMIP3 data and served at: http://gdodcp.ucllnl.org/downscaled_cmip3_projections/, described by Maurer et al (2007).

The resolution of these datasets is monthly, 1/8th degree gridded products for both the Boise River and the Spokane River basins. Since we required daily precipitation and temperature data for hydrological modeling, we temporally disaggregated to a daily time step. There is a six-step procedure we performed to temporally disaggregate the GCM climate model data downloaded from the link above. 1. Randomly pick a historical year to compute mean of the daily precipitation and temperature of the gridded observed record for the same month as the future year; 2 .

Calculate the difference between future monthly mean temperature and historical mean of monthly mean temperature, ' $\Delta t$ '; 3 . Calculate the ratio between future monthly mean precipitation and historical mean of monthly mean precipitation, ' $r$ '; 4 . Add " $\Delta \mathrm{t}$ " to daily temperature of the month of the randomly selected year; multiply daily precipitation by " $r$ " for the month of randomly selected year; 5. Continue step 1-4 for other months of the year for future years; and 6. Repeat these steps for the remaining grid cells. Using these downscaled climate model outputs, we simulated streamflows for each scenario including the magnitude and timing of flow. These estimates included simulations through 2060 at ten year intervals. 

available at www.blackwell-synergy.com. DOI: 10.1111/j.1752-1688.2011.00605.x

\section{Hydrologic Modeling}

\subsection{Boise River Basin}

The Boise River is a tributary of the Snake River in southwestern Idaho with a drainage area of $10,619 \mathrm{~km}^{2}$ (Figure 1(a)). The Boise River originates from the three forks of the Sawtooth Range that subsequently join together at the Arrowrock Reservoir to form the mainstream flowing west through the Snake River Plain that finally merges with the Snake River at Parma. Topography has west to east gradient, exceeding $3000 \mathrm{~m}$ at the Sawtooth Range and low elevation of $640 \mathrm{~m}$ feet in the western part near Parma. The basin receives precipitation in the wintertime and the spring snowmelt-induced runoff, which begins in the lower elevations around March, typically continues to contribute a significant amount of streamflow from the high mountains into July. The peak flow period is followed by a relatively dry warm summer. During the fall season, due to reduced transpiration and autumn rainfall as well as the groundwater contribution to baseflow, the streamflow increases slightly. The average annual precipitation in the basin is $661 \mathrm{~mm}$ and average annual mean temperature is $5.9^{\circ} \mathrm{C}$. The land cover in this area is highly diverse, including alpine canyons, forest, rangeland, agriculture land and urban area (Figure 2(a)). The eastern part of the basin (upstream of Lucky Peak Dam) is mainly covered by forests. The lower part of the river basin is covered by grassland, cultivated crops and developed urban areas.

\subsection{The Spokane River Basin}

The Spokane River is located in the northern Idaho and eastern Washington with a drainage area of $17,200 \mathrm{~km}^{2}$ (Figure 1 (b)). It rises from Lake Coeur d'Alene, Idaho and flow west through the Spokane Valley until reaching Spokane, WA. The elevation of the basin increases from west to east and the upper forested catchments receive higher precipitation. The general climate in this area is warm and dry summer (mean temperature $16^{\circ} \mathrm{C}$, total precipitation in winter is $130 \mathrm{~mm}$ ), while cold and moist winter (mean temperature $-3.4^{\circ} \mathrm{C}$, total precipitation during winter is $328 \mathrm{~mm}$ ). The average annual total precipitation is $878 \mathrm{~mm}$ and average annual mean temperature is $6.2^{\circ} \mathrm{C}$. More than $2 / 3$ of the precipitation $(319 \mathrm{~mm})$ is received in the winter as snow. The average annual evaporation is $420 \mathrm{~mm}$ that is approximately $49 \%$ of the average annual precipitation. The aquifer, known as the Spokane Valley Rathdrum Prairie aquifer (SVRP), is extending from Lake Pend Oreille, Idaho to Spokane, Washington. It is the "sole water aquifer" for its 500,000 population and the aquifer is heavily extracted due to rapid growth in the region and its area is $830 \mathrm{~km}^{2}$ covering the two states. There are a number of lakes surrounding this aquifer that serves as the sources for recharge in addition to precipitation. A series of flooding occurred during the last Glacial Age and made the soil in SVRP primarily unconsolidated coarse-grained sands, gravels, cobbles and boulders with relatively high hydraulic conductivity (Barber et al, 2009). As a result, there is a strong surface water and groundwater interaction between this aquifer and the Spokane River. Reach gains and losses are interlacing from Post Falls, Idaho to Spokane, WA. Land cover in this watershed is dominated by forests and other land cover types include urban or suburban area in the SVRP area and agriculture in the western part of the watershed (Figure 2(b)).

\subsection{Calibration for the Boise River Basin}

The Soil Water Assessment Tool (SWAT) model has been implemented for this study. This watershed scale model is well-tested, widely used and runs with readily available inputs in Geographic Information System (GIS). For datalimited, complex terrain such as ours, this model provides the firsthand information on the hydrological processes relatively easily. Furthermore, we have customized this model for other Idaho watersheds earlier (Stratton et al., 2009, Sridhar and Nayak, 2010). The basic drivers for this model are USGS-derived Digital Elevation Model, STATSGO soil layer, National Land Cover Data 2001 for vegetation and weather data. We divided the entire basin into 140 sub-basins to represent the spatial heterogeneity of the basin in the model. We also used 74 grids at the $1 / 8^{\text {th }}$ degree resolution to drive the hydrology model with GCM-produced precipitation and temperature after downscaling them as explained above.

Based on the sensitivity analysis and manual verification, we identified 16 parameters of interest for this basin. We started with all 27 hydrological flow-related parameters and ranked by their order of sensitivity in simulating the basin hydrology. It resulted in about 10 parameters as the most sensitive ones for this basin. We then manually added additional parameters that were considered to be important for capturing the basin scale hydrological processes. For instance, even if the model sensitivity analysis did not consider melt factor as an important one to be 
calibrated, we included it manually. Followed by the sensitivity analysis and manual evaluation, we included 16 parameters for our next calibration procedure.

The identified parameters were SCS curve number, deep aquifer percolation fraction, maximum canopy storage, soil depth, threshold water depth in the shallow aquifer, available soil water capacity, saturated hydraulic conductivity, channel effective hydraulic conductivity, soil evaporation compensation factor, plant uptake compensation factor, ground water delay, deep aquifer percolation fraction, surface runoff lag time, snow pack temperature lag factor and snow melt base temperature. These parameters with their optimal values are shown in Table $2(\mathrm{a} \& \mathrm{~b})$. These were considered optimal based on the objective functions, correlation coefficient $\left(\mathrm{R}^{2}\right)$ and Nash-Sutcliff Efficiency (NSE) index. For monthly calibration, as performed in this study, Stratton et al. (2009) suggested that an $\mathrm{R}^{2}$ of greater than or equal to 0.6 is desirable. We additionally considered an NSE factor as another metric for calibration. It can be inferred from our statistical analysis that these metrics rely on the quality of the observed streamflow data as well as spatial and temporal distribution of streamflow gages. Therefore, after identifying the sensitive parameters for both the basins, we generated the optimum parameters based on the autocalibration function, Sequential Uncertainty Fitting Version 2 (SUFI2) calibration algorithm which is explained below. The lower bound and upper bound columns indicate the range a given parameter can move in space while calibrating it. Also, there are options for the parameter estimation within this algorithm, known as IMET options, for replacement, multiplication and addition/subtraction and here we used replacement or multiplication options.

SUFI2 (Sequential Uncertainty Fitting Version2) is a program that is linked with SWAT for calibration. This optimization method calibrates the parameter to achieve best fitness and to the maximum degree to account for the uncertainty between the simulated and measured data. The metric used in this calibration procedure is R-factor and P-factor (Abbaspour, 2008). The calibration process is to adjust the parameter values to make R-factor close to 1 and P-factor close to 0 . This program includes several steps: 1. Define the objective function; 2. Define the initial range of the parameters; 3. Perform the sensitivity analysis (optional, but highly recommended); 4. Employ the Latin Hypercube Sampling (LHS) approach of the parameters. The common number of combinations of parameters is $\mathrm{n}=500-1000 ; 5$. Run the simulation $n$ times and save the simulated output variables of interest, corresponding to the measurement; 6. Calculate the objective function; 7. Calculate the metrics for fitness and uncertainty; 8 . Adjust the range of parameters and repeat "1". By this way, the optimal set of parameters is obtained for the subsequent simulation. SWAT is a HRU-based model that makes the parameters distributed for each HRU. This may be tedious to collect or estimate a large number of parameters for a simulation of even a small watershed. In order to facilitate the calibration of such distributed parameters, SUFI2 has been improved to accommodate the aggregate of parameters. This is implemented by encoding the extended parameters to include the information on what locations to apply a parameter value and hence to aggregate the parameters and this format is adopted in our research.

Historic period was divided into calibration (1958-1963) and validation (1964-2004) windows for this analysis. This splitting of calibration and validation is essential in order to evaluate the performance of the model independent of the calibration effects. The SWAT model was calibrated and verified at five locations (Twin Springs, Anderson Ranch Reservoir, Arrowrock Reservoir, Lucky Peak Reservoir and Parma) in the Boise River basin and two locations (Post Falls and Spokane) in the Spokane River basin, thus covering the large areas of both the basins. The locations were chosen based on the availability of data from U.S Geological Survey (USGS) and the outflow points identified after subdividing the basins into subbasins in the model. Also, it was preferred to distribute the locations from upstream to downstream sections in order to study the impacts and variability of the watershed hydrology due to climate change. Note that some parameters are calibrated at finer scales, which is known as, Hydrological Response Unit (HRU). These HRUs were based on the unique combination of soil, vegetation and slope and are derived from the GIS layers by overlaying them and the total number of HRUs exceeded over 5500. Some other parameters were calibrated at the subbasin level while the remaining parameters were at the basin level.

The selected parameters were subsequently employed for historical hydrological simulations. Statistical results $\left(\mathrm{R}^{2}\right.$ $>0.7$ and Nash-Sutcliff Efficiency >0.7) of calibration and historical validation of streamflows are shown in Table 3. Validation of Twin Springs and Anderson Ranch were slightly less when compared with the other sites with NSE of about 0.65 . However, both the sites have an $\mathrm{R}^{2}$ greater than 0.8 for the validation period. It is generally expected the validation period statistics will be similar or slightly inferior to that of the calibration period statistics. Streamflow data used for calibration could be attributed to this decreased NSE in addition to the parameters related to snow-melt induced runoff in these forested upstream locations. 
This is an author-produced, peer-reviewed version of this article. The final, definitive version of this document can be found online at $J A W R A$ :

Journal of the American Water Resources Association, published by Wiley-Blackwell. Copyright restrictions may apply. The definitive version is available at www.blackwell-synergy.com. DOI: 10.1111/j.1752-1688.2011.00605.x

Capturing both low flows and high flows was considered as a prerequisite for our implementation of the model with the calibrated parameters under the climate change scenarios. As changes to the hydrologic conditions are expected to occur rapidly in the future, knowing the historic behavior of flows and hydrology as the baseline reference is critical. Streamflows simulated for historical conditions showed good correlation both in terms of peak flow magnitudes and the timing of snowmelt for the historic climate conditions. Figure 3 shows the correlation between the model-simulated streamflow and observed natural flow for Twin Springs and Lucky Peak. Natural or unmanaged high flows ranged between $113-170 \mathrm{~m}^{3} / \mathrm{s}$ for the upstream locations and $340-450 \mathrm{~m}^{3} / \mathrm{s}$ for the downstream gaging stations and low flows were between $28-57 \mathrm{~m}^{3} / \mathrm{s}$ in the Boise River basin. Flows at Twin Springs, Anderson Ranch, Arrow Rock, Lucky Peak, Glenwood, Middleton, Caldwell and Parma were verified. Our simulation also showed that interannual variability in streamflows was relatively high for the Boise River basin for the historic climatic conditions. Other water balance components (evapotranspiration, soil moisture, recharge) were analyzed. Evapotranspiration accounted for $50-60 \%$ of total precipitation annually. Soil moisture and recharge accounted for about $10-15 \%$ of annual precipitation.

\subsection{Calibration for the Spokane River Basin}

Similar to earlier implementation, the SWAT model was configured to run for the whole of Spokane River basin in order to establish the hydrologic connectivity and the watershed characterization including the aquifer. To understand the flow pattern in the upstream portion of the Spokane River basin which lies in Idaho, it is essential to consider the entire watershed beyond Idaho borders. Therefore, our delineation of the basin includes both the regions in Idaho and Washington. There are 226 sub-basins and over 5700 HRUs derived from a combination of DEMs, slope and soil layers and 144 weather points within this basin to drive the model with the GCM data.

We identified 15 sensitive parameters for this basin and they included surface flow, groundwater, soil and snow parameters similar to that of the Boise River region. Initial calibration was performed by dividing the region above Post Falls and the region below Post Falls. A combination approach of autocalibration using SUFI algorithm followed by manual calibration for the Post Falls and Spokane streamflow stations showed good correlation for the historic period. Optimum values of the parameters are shown in Table 4. The parameters that we calibrated were baseflow factor, maximum canopy storage, SCS curve number, deep aquifer percolation fraction, soil evaporation compensation factor, plant uptake compensation factor, ground water delay, deep aquifer percolation fraction, threshold water depth in the shallow aquifer, available soil water capacity, saturated hydraulic conductivity, channel effective hydraulic conductivity, surface runoff lag time, snow pack temperature lag factor and snow melt base temperature.

The calibrated SWAT model was verified at two locations (Post Falls and Spokane) in the Spokane River basin, thus covering the large areas of the Spokane River basin (Figure 4). Both seasonality and peakflows were captured by the model under historic climate conditions. Statistical results with $\mathrm{R}^{2}>0.65$ and Nash-Sutcliff Efficiency $>0.55$ for the calibration and historical validation with $\mathrm{R}^{2}>0.66$ for the model performance in predicting streamflows are shown in Table 5. However, for the second validation period, 1981-99, both $\mathrm{R}^{2}(0.66)$ and NSE (0.41) have shown a slightly inferior performance of the model. Normally, the validation period statistics is somewhat lower when compared against the calibration period and we found it to be the case in this study also. However, the correlation coefficient of 0.6 was considered reliable in order for us to use this as a predictive tool in our hydrological impact analysis.

For the Spokane River basin, high flows ranged between $560-850 \mathrm{~m}^{3} / \mathrm{s}$. Historic climate analysis showed that interannual variability in streamflow was relatively high for the Bois River basin. However, this was slightly less in the Spokane River basin which can be attributed to precipitation variability in the historic climatic conditions. There was an earlier snowmelt for both the regions as a result of increasing temperature trends, especially at lower elevations. Streamflows simulated by the model was verified against the observations. Figure 8 shows the time series of streamflows captured by the model for Post Falls and Spokane gaging stations. 


\section{Results and Discussion}

\subsection{Future trends in temperature and precipitation}

We have assessed the climate change impacts using the GCM-produced, downscaled precipitation and temperature on the Boise River and Spokane River basins' hydrology and water resources. All of the ensemble members, comprising of all 5 GCMs for 3 scenarios (a total of 15 members) are shown for each decade between 2010 and 2060 in Table 6. For the Boise River region, changes in precipitation ranged between $-3.8 \%$ to $36 \%$ (A2), $-9 \%$ to $35 \%$ (A1B) and B1 (-6.7\% to 30.5\%). However, changes in temperature were expected to be between $0.02-3.6{ }^{\circ} \mathrm{C}$ (A2), 0.8-3.9 ${ }^{\circ} \mathrm{C}(\mathrm{A} 1 \mathrm{~B})$ and $0.5-3.1{ }^{\circ} \mathrm{C}(\mathrm{B} 1)$ (Table 6(a)). In the Spokane River region, changes in precipitation were expected to be between $-3.8 \%$ to $14 \%$ (A2), $-6.7 \%$ to $17.9 \%$ (A1B) and $-7.4 \%$ to $14.3 \%$ (B1). Changes in temperature were likely to be $0.1-3.2{ }^{\circ} \mathrm{C}(\mathrm{A} 2), 0.8-3.5^{\circ} \mathrm{C}(\mathrm{A} 1 \mathrm{~B})$ and $0.3-2.7{ }^{\circ} \mathrm{C}(\mathrm{B} 1)$. Overall, the chosen climate models showed a rise in temperature $\left(0.31{ }^{\circ} \mathrm{C}\right.$ to $0.42{ }^{\circ} \mathrm{C} /$ decade for Spokane River and $0.34{ }^{\circ} \mathrm{C}$ to $\left.0.46{ }^{\circ} \mathrm{C} / \mathrm{decade}\right)$ and an increase in annual precipitation (4.7\% to 5.8\% for Spokane River and 5.3\% to 8.5\% for Boise River) over a period of next five decades between 2010-2060 (Table 6 (b)) (Figure 5 and Figure 6). The precipitation forecast was less certain than the temperature trends as there was less agreement among the models. This was generally the case even at the global scale and therefore selecting the global climate for a given application is important (Pierce et al., 2009). However, the temperature increase was found to be consistent among the models considered in this study. In general, both the regions were expected to see increased annual precipitation (4-8\%) and temperature $(0.31-0.45$ ${ }^{\circ} \mathrm{C} /$ decade) when averaged over all the GCMs.

\subsection{Translating climate model outputs to regional water resources assessment}

As a result of the increased precipitation and temperature outlooks, generally both the regions were expected to have increased streamflows during the peak flow season (Figure 7) and decreased flows in the summer. With all the climate scenarios that have been analyzed in the study, a wide range of predictions was probable for the entire 50 year period between 2010 and 2060. The choice of the climate model in understanding the future flow pattern again becomes important. This was observed for all emission scenarios, i.e. A1B, A2 and B1, where we projected mostly increased precipitation possibilities and the range of peak flows (March through June) were expected to increase by $106 \mathrm{~m}^{3} / \mathrm{s}$ (A2), $84 \mathrm{~m}^{3} / \mathrm{s}$ (A1B) and $101 \mathrm{~m}^{3} / \mathrm{s}$ (B1). This was based on the average of eight sites in the Boise River basin where flows were predicted by the model. However, there were uncertainties in these predictions as evidenced from decreases in peak flows predicted in some scenarios. An eight site average of decrease in peak flows for the Boise River basin revealed the flows as $58 \mathrm{~m}^{3} / \mathrm{s}$ (A2), $70 \mathrm{~m}^{3} / \mathrm{s}$ (A1B) and $60 \mathrm{~m}^{3} / \mathrm{s}$ (B1). These could be due to some scenarios where precipitation was predicted to be decreasing.

As in Figure 8, in the Spokane River basin the peak flows increases were expected to be about $88 \mathrm{~m}^{3} / \mathrm{s}(\mathrm{A} 2), 34 \mathrm{~m}^{3} / \mathrm{s}$ (A1B) and $70 \mathrm{~m}^{3} / \mathrm{s}$ (B1) based on the two site average flows predicted by the model. However, the decreases in peakflows were also higher than that of the Boise River Basin. For instance, a decrease in peak flows by $190 \mathrm{~m}^{3} / \mathrm{s}$ (A2), $198 \mathrm{~m}^{3} / \mathrm{s}$ (A1B) and $154 \mathrm{~m}^{3} / \mathrm{s}$ (B1) are also simulated by some scenarios. This decrease in peak flow magnitude was much higher in the Spokane River basin. Precipitation uncertainty causing flow variations appears to be magnified in the higher latitudes for both the basins. However, nearly all scenarios agree that there will be a slight advancement in the timing of melt in the Boise River and the Spokane River basins.

The volume of streamflow in the low flow period (July through Oct) was also possibly increasing minimally in the Boise River basin. More specifically, the average increase in the summertime flows were $25 \mathrm{~m}^{3} / \mathrm{s}(\mathrm{A} 2), 23 \mathrm{~m}^{3} / \mathrm{s}$ (A1B) and $30 \mathrm{~m}^{3} / \mathrm{s}$ (B1) scenarios. The lower range in the low flows predicted by the model have projected decreasing flows by $3 \mathrm{~m}^{3} / \mathrm{s}$ (A2 and A1B) and $5 \mathrm{~m}^{3} / \mathrm{s}$ (B1). Notably, the range of changes in the low flows from historical conditions was not deviating significantly (Figure 9). The summertime low flow changes in the Spokane River basin appeared to have increased low flows when compared against the historic conditions (Figure 10). For instance, a flow change of $140 \mathrm{~m}^{3} / \mathrm{s}$ (A2), $135 \mathrm{~m}^{3} / \mathrm{s}$ (A1B) and $131 \mathrm{~m}^{3} / \mathrm{s}$ (B1) was predicted. It is also clear that some scenarios predicted a low flow change during the same summertime with only minimal change from historic flows. A minimal increase, rather than a decrease as in the Boise River region, by $8 \mathrm{~m}^{3} / \mathrm{s}(\mathrm{A} 2), 9 \mathrm{~m}^{3} / \mathrm{s}(\mathrm{A} 1 \mathrm{~B}) \mathrm{and}^{3} \mathrm{~m}^{3} / \mathrm{s}$ (B2) was simulated by these models. 
The entire range of change in flows from historic conditions by magnitude and percentage for the Spokane River (Post Falls, Spokane) and the Boise River (Twin Springs, Anderson Ranch, Arrowrock, Lucky Peak, Glenwood, Middleton, Caldwell and Parma) were calculated but we showed only for few sites in this report. The change in flows (both magnitude and percentage) was computed as the difference between historic averages of monthly flow to future flow. It appeared that natural flows between Caldwell and Parma have increased by about two or three times historically based on the natural flow data analysis from IDWR. If it was due to ground water pumping and the reach gains were added to the natural flow or diversion from the Payette River to augment the Boise River flow, it was reasonable to observe increased flows in a short distance given the geologic conditions of the basin. An additional accumulation of flow between Caldwell and Parma was not captured by the model. This additional volume of water could be due to irrigation return flow to the stream and natural recharge. It also depends on the information on the management of groundwater and surface water, diversion and flow augmentation in the Boise River system.

\subsection{Hydrologic Mass Balance estimates under future climate}

Precipitation being the main driver in the water balance computation, its variability both annually and seasonally has a direct impact on the other simulated water budget components. As shown in Figure 11, the Spokane River region was anticipated to receive in the future about $910 \mathrm{~mm}$ of precipitation on average of which about $40-50 \%$ of it allocated to evapotranspiration $(400 \mathrm{~mm})$ and $15-20 \%$ of it partitioned to recharge which was essentially $100-200$ $\mathrm{mm}$ in a year. Streamflow referred as water yield (blue line with circles) ranging between $250-500 \mathrm{~mm}$ could be seen from Figure 16. Historic recharge was between $25-500 \mathrm{~mm}$ by various methods of recharge estimation over the Spokane River basin (Bartolino, 2007). On average, evapotranspiration was expected to be between $230-280 \mathrm{~mm}$ in the Boise River basin and 380-430 $\mathrm{mm}$ in the Spokane River region, which was about $40-50 \%$ of the annual projected precipitation. This did not include the effects of irrigation in the water budget. Sridhar and Nayak (2010) and Stratton et al., (2009) reported that about $50-60 \%$ of annual precipitation was partitioned into evapotranspiration historically in the Idaho watersheds.

The major water balance components including precipitation, streamflow, soil moisture, evapotranspiration and recharge by decade for each scenario (A2, A1B and B1) based on the chosen climate model predictions were analyzed. In the Boise River basin, precipitation ranged from 580-890 $\mathrm{mm}$, which appears to cause significant ranges in streamflow between $250-480 \mathrm{~mm}$ and recharge from $100-200 \mathrm{~mm}$ among the models for the three emission scenarios. The other two components, evapotranspiration and soil water storage, under natural conditions (without any human influence) as predicted by these models have shown lesser variability.

In the Spokane River basin, precipitation was expected to range between $800-1000 \mathrm{~mm}$ over the next decades, thereby causing a wide range in streamflow estimates $(350-500 \mathrm{~mm}$ ) and moderate recharge between $50-100 \mathrm{~mm}$. Evapotranspiration varied between 380 and $480 \mathrm{~mm}$ under natural vegetation conditions. Soil water projections were between $150-200 \mathrm{~mm}$. The range of variability is quite apparent for both the basins.

\section{Summary and Conclusions}

This investigation covered many tasks including the evaluation of climate models, climate model output downscaling, SWAT model calibration and validation, simulation of climate change in the basin's hydrology and assessment. We identified five climate models that are relevant to capturing the future trends in precipitation and temperature. The models included CCSM3 (warmer and dry summer through 2020), HADCM3 (warmer and dry summer through 2040), IPSL CM4 (wetter winter), MIROC 3.2 (warmer and wetter winter) and PCM (cooler and dry summer). They represented a wide range of conditions and also change by time. After identifying the models, we downloaded the spatially downscaled climate model data from CMIP3 source developed by Bureau of Reclamation and other collaborators and subsequently temporally disaggregated them from monthly to daily to run the hydrology model. Some models predicted an increase in precipitation between 2010 and 2060 while other models predicted a decrease for the same period. However, temperature increase was found to be consistent. For the Boise River region, changes in precipitation ranged between $-3.8 \%$ and $36 \%$. Changes in temperature were expected to be between 0.02 and $3.9^{\circ} \mathrm{C}$. In the Spokane River region, changes in precipitation were expected to be between $-6.7 \%$ and $17.9 \%$. Changes in temperature were anticipated to be ranging between 0.1 and $3.5^{\circ} \mathrm{C}$. Overall, the chosen climate models showed a rise in temperature $\left(0.31{ }^{\circ} \mathrm{C}\right.$ to $0.42{ }^{\circ} \mathrm{C} /$ decade for the Spokane River basin and 
$0.34{ }^{\circ} \mathrm{C}$ to $0.46{ }^{\circ} \mathrm{C} /$ decade for the Boise River basin) and an increase in annual precipitation $(4.7 \%$ to $5.8 \%$ for the Spokane River and $5.3 \%$ to $8.5 \%$ for the Boise River) over a period of next five decades between 2010-2060.

In order to study the response of the hydrology model due to changes in precipitation, we implemented the SWAT hydrology model to simulate the basin scale hydrologic response to changing climate. However, it is critical to calibrate the model based on the observed flow for multiple sub-basins in each basin. Therefore, we first calibrated the SWAT model for the Spokane River basin using the flows from Post Falls and Spokane. Similarly, we calibrated the model for the Boise River basin using the flows from Parma, Lucky Peak, Arrowrock, Twin Springs and Anderson Ranch. This calibration exercise resulted in 16 parameters adjusted for various processes within the basin including snowmelt, vegetation, groundwater and surface runoff. In both the basins the model performance was evaluated using the $\mathrm{R}^{2}$ values and we obtained a value of 0.6 or higher and that was considered to be good in the modeling environment for extending the simulation framework with selected parameters to another period.

The SWAT hydrology model was implemented under future climate conditions using the newly calibrated parameters. Considering a wide range of precipitation and temperature outlook, we expected predictions about the basin hydrology to express a broad range in streamflows, evapotranspiration and recharge during the simulation period of the entire 50 year period between 2010 and 2050. This was observed for all emission scenarios, A1B, A2 and B1 and based on the average of eight sites (Twin Springs, Anderson Ranch, Arrowrock, Lucky Peak, Glenwood, Middleton, Caldwell and Parma) in the Boise River basin the peak flows (March through June) appeared to range between -58 to $+106 \mathrm{~m}^{3} / \mathrm{s}$. We averaged the two site predictions (Post Falls and Spokane) in the Spokane River basin to understand the peak flow trends. It was found that changes in flows were expected to be between $-198 \mathrm{~m}^{3} / \mathrm{s}$ and $+88 \mathrm{~m}^{3} / \mathrm{s}$ by some scenarios. The low flows (July-Oct) predicted by the model have projected decreasing flows between $3-5 \mathrm{~m}^{3} / \mathrm{s}$ in the Boise River basin. In the Spokane River basin, a flow increase by $130-140 \mathrm{~m}^{3} / \mathrm{s}$ was predicted. There are some uncertainties as shown in our estimates wherein the lower range in the increase of low flows was simulated to range between 2 to $9 \mathrm{~m}^{3} / \mathrm{s}$ for the Spokane River basin.

We also anticipate a shift in the timing of snowmelt and this shift is advancing from current peak melt period of May to April. This has been consistent for both the basins. This is pretty typical of many regions in the Western U.S. which is expected to cause some management problems related to the water resources in the region. An earlier melt, if not stored, might cause some shortages in the system thereby possibly impacting various sectors including irrigated agriculture, hydro power and domestic as well as municipal water supply.

In the Boise River basin, depending on the climate scenario, a range in precipitation between 580 and $890 \mathrm{~mm}$ was probable and it could have the cascading effect on the hydrological water balance components. For instance, streamflows predicted by the model were between 250 to $480 \mathrm{~mm}$ and recharge from 100 to $200 \mathrm{~mm}$. The other two components, evapotranspiration and soil water storage although were expected change, under natural condition (without any human influence) as predicted by these models have shown lesser variability. In the Spokane River basin, precipitation was expected to range between $810-1000 \mathrm{~mm}$ over the next decades, which in turn appeared to cause a range in streamflow $(350-500 \mathrm{~mm})$ and recharge $(50-100 \mathrm{~mm})$ estimates. Evapotranspiration varied between $380-480 \mathrm{~mm}$ under natural vegetation conditions. Soil water projections were between $150-200 \mathrm{~mm}$. It is also important to recognize that there are some uncertainties in our estimates and that can be attributed to GCM-produced precipitation and temperature, model parameters and structure (for instance reach gain or loss, residence time of aquifer recharge) and measured regulated flow, computed natural flow and its year-to-year variability. A broad range in hydrologic predictions amply points out that the choice of climate model and hydrologic model calibration is essential to get useful estimates of future hydrologic and water resources at the very local scale. It is also critical to provide a range of hydrologic outcomes as the uncertainty in climate model predictions are relatively large and this in a way helps water managers and stakeholders alike in the watershed to evaluate various options that will be available at their disposal for decision making on the future water availability.

\section{Acknowledgments}

The research reported in this paper was supported in part by the Idaho Department of Water Resources under contract number CON00837, US Geological Survey Award Number 06HQGR0082 and NSF-Idaho EPSCoR Program and the National Science Foundation under award number EPS-0814387. 


\section{Literature Cited}

Abbaspour, K., 2008. SWAT-CUP2: SWAT Calibration and Uncertainty Programs - A User Manual, Department of Systems Analysis, Integrated Assessment and Modelling (SIAM), Eawag, Swiss Federal Institute of Aquatic Science and Technology, Duebendorf, Switzerland, 2008, 95pp.

Barber, M.E., A. Hossain, J.J. Covert, and J.G. Gregory, 2009. Augmentation of Seasonal Low Stream Flows by Artificial Recharge in the Spokane Valley-Rathdrum Prairie Aquifer of Idaho and Washington, USA.

Hydrogeology Journal 17: 1459-1470.

Barnett, T.P., D.W. Pierce, H.G. Hidalgo, C. Bonfils, B.D. Santer, T. Das, G. Bala, A.W. Wood, T. Nozawa, A.A. Mirin, D.R. Cayan, M.D. Dettinger, 2008. Human-induced Changes on the Hydrology of the Western United States. Science 106(18): 7334-7338.

Bartolino, J.R., 2007. Assessment of Areal Recharge to the Spokane Valley-Rathdrum Prairie aquifer, Spokane County, Washington, and Bonner and Kootenai Counties, Idaho. Scientific Investigations Report 2007-5038, US Department of Interior, US Geological Survey, 48pp.

Caprio, J.M., H.A. Quamme, and K.T. Redmond, 2009. A Statistical Procedure to Determine Recent Climate Change of Extreme Meteorological Data as Applied at Two Locations in the Northwestern North America. Climatic Change 92(1-2): 65-81.

Christidis, N., P.A. Stott, S. Brown, D.J. Karoly, and J. Caesar, 2007. Human Contribution to the Lengthening of the Growing Season during 1955-1999. Journal of Climate 20(21):5441-5454.

Folland, C.K., N.A. Rayner, S.J. Brown, T.M. Smith, S.S.P. Shen, D.E. Parker, I. Macadam, P.D. Jones, R.N. Jones, N. Nicholls, and D.M.H. Sexton, 2001. Global Temperature Change and its Uncertainties since 1861. Geophysical Research Letters 28: 2621-2624, DOI:10.1029/2001GL012877.

Hamlet, A.F., and D.P. Lettenmaier, (1999). Effects of Climate Change on Hydrology and Water Resources in the Columbia River Basin. Journal of American Water Resources Association 35(6):1597-1632.

Hidalgo, H.G., T. Das, M.D. Dettinger, D.R. Cayan, D.W. Pierce, T.P. Barnett, G. Bala, A. Mirin, A.W. Wood, C. Bonfils, B.D. Sander, and T. Nozawa, 2009. Detection and Attribution of Streamflow Timing Changes to Climate Change in the Western United States. Journal of Climate 22(13): 3838-3855.

Hseih, P.A., M.E. Barber, B.A. Contor, M.A. Hossain, G.S. Johnson, J.L. Jones, and A.H. Wylie, 2007. Groundwater Flow Model for the Spokane Valley-Rathdrum Prairie Aquifer, Spokane County, Washington, and Bonner and Kootenai Counties, Idaho. USGS Scientific Investigations Report 2007-5044, Reston, VA.

Kunkel, K.E., D.R. Easterling, , K. Hubbard, , K. Redmond, , 2004. Temporal Variations in Frost-free Season in the United States 1895-2000. Geophysical Research Letters, 31, L03201, doi:10.1029/2003GL018624.

Maurer, E. P., L. Brekke, T. Pruitt, and P.B. Duffy, 2007. Fine-resolution Climate Projections Enhance Regional Climate Change Impact Studies. Eos Trans. AGU, 88(47), 504.

Mote, P.M., and E.P., Salathé, 2009. Future Climate in the Pacific Northwest. JISAO Climate Impacts Group, University of Washington, Seattle, WA 98195-5672.

Mote, P.W., 2003. Trends in Temperature and Precipitation in the Pacific Northwest during the Twentieth Century. Northwest Science 77(4):271-282.

Mote, P.W., 2006. Climate-driven Variability and Trends in Mountain Snowpack in Western North America. Journal of Climate 19(23): 6209-6220. 
Mote, P.W and E.P. Salathé, 2009. Future Climate in the Pacific Northwest. Climate Impacts Group, Joint Institute for the Study of the Atmosphere and Ocean, University of Washington, 13pp.

Payne, J.T., A.W. Wood, A.F., Hamlet, R.N. Palmer, and D.P. Lettenmaier, 2004. Mitigating the Effects of Climate Change on Water Resources in the Columbia River Basin. Climatic Change 62(1-3): 233-259.

Pierce, D.W., T.P. Barnett, H.G. Hidalgo, T. Das, , C. Bonfils, B.D. Santer, G. Bala, M.D. Dettinger, D.R. Cayan, A. Mirin, A.W. Wood, and T. Nozawa, 2008. Attribution of Declining Western U.S. Snowpack to Human Effects.

Journal of Climate 21(23): 6425-6444.

Pierce, D.W., T.P. Barnett, D.B. Santer, and J.P. Gleckler, 2009. Selecting Global Climate Models for the Regional Climate Change Studies. PNAS106: 8441-8446.

Sridhar, V., and A. Nayak 2010. Implications of Climate-driven Variability and Trends for the Hydrologic Assessment of the Reynolds Creek Experimental Watershed, Idaho. Journal of Hydrology, 385, 183-202, doi:10.1016/j.jhydrol.2010.02.020.

Stewart, I.T., D.R. Cayan, M.D. Dettinger, 2005. Changes toward Earlier Streamflow Timing across Western North America. Journal of Climate 18(8): 1136-1155.

Stratton, B.T., V. Sridhar, M.M. Gribb, J.P. McNamara, and B. Narasimhan, 2009. Modeling the spatially Varying Water Balance Processes in a Semi-arid Mountainous Watershed of Idaho. Journal of the American Water Resources Association, 45 (6) , 1390-1408, DOI: 10.1111/j.1752-1688.2009.00371.x. 


\section{List of Tables}

Table 1. Table 1. List of Global Climate Models employed in this study

Table 2. T able 2 (a). Calibration of the SWAT model using Sequential Uncertainty Fitting algorithm to obtain the optimum parameters representing the basin characteristics for four calibration sites (Lucky Peak, Arrowrock, Anderson Ranch, Twin Springs) in the Boise River Basin.

Table 2 (b). Calibration of the SWAT model using Sequential Uncertainty Fitting algorithm to obtain the optimum parameters representing the basin characteristics for Parma in the Boise River Basin.

Table 3. Calibration and Validation statistics for various gaging locations in the Boise River Basin.

Table 4. Calibration of the SWAT model using Sequential Uncertainty Fitting algorithm to obtain the optimum parameters representing the basin characteristics in the Spokane River Basin.

Table 5. Calibration and Validation statistics for various gaging locations in the the Spokane River Basin.

Table 6. (a) The Boise River Basin Future Temperature and Precipitation changes for each decade between 20102060 for each scenario (A2, A1b and B1) (b) The Spokane River Basin Future Temperature and Precipitation changes for each decade between 2010-2060 for each scenario (A2, A1B and B1). 
This is an author-produced, peer-reviewed version of this article. The final, definitive version of this document can be found online at $J A W R A$ : Journal of the American Water Resources Association, published by Wiley-Blackwell. Copyright restrictions may apply. The definitive version is available at www.blackwell-synergy.com. DOI: 10.1111/j.1752-1688.2011.00605.x

\section{$\underline{\text { List of Figures }}$}

Figure 1. Location map showing the Boise River Basin (top) and the Spokane River Basin (bottom) Figure 2. Land use map used in the SWAT model from National Land Cover Data set for the Boise River Basin (top) and the Spokane River Basin (bottom)

Figure 3. Streamflows for Twin Springs and Lucky Peak simulated by the SWAT model during (a) calibration (1959-1963) and (b) validation period (1964-2004).

Figure 4. Streamflows for Post Falls and Spokane simulated by the SWAT model during (a) calibration (1978-1981) and (b) validation period (1953-1977; 1982-2000).

Figure 5. Temperature (top) and Precipitation (bottom) trends under climate change conditions for the Boise River basin between 2010 and 2060. The models used are CCSM3, HADCM3, IPSL CM4, MIROC 3.2 and PCM.

Figure 6. Temperature (top) and Precipitation trends under climate change conditions for the Spokane River basin between 2010 and 2060. The models used are CCSM3, HADCM3, IPSL CM4, MIROC 3.2 and PCM.

Figure 7. Seasonal streamflows for each decade between 2010 and 2060 at Twin Springs in the Upper Boise River basin for each scenario for A1B (top), A2 (middle) and B1 (bottom). Higher peak flows are expected to occur in May and low flows are about the same or slightly above when compared against the historic flows.

Figure 8. Seasonal streamflows for each decade between 2010 and 2060 at Post Falls in the Spokane River Basin for each scenario for A1B (top), A2 (middle) and B1 (bottom). Higher peak flows are expected to occur in May and low flows are about the same or slightly above when compared against the historic flows.

Figure 9. Low flows for each decade between 2010 and 2060 at Twin Springs, Caldwell and Parma in the Boise River Basin.

Figure 10. Low flows for each decade between 2010 and 2060 at Post Falls in the Spokane River Basin. Low flows are about the same or slightly below when compared against the historic flows.

Figure 11. Annual Water balance estimates for Boise River (top) basin and Spokane River basin (bottom) averaged over all GCMs and scenarios (15 members). 
Table 1. List of Global Climate Models employed in this study

\begin{tabular}{|c|c|c|c|}
\hline Model & Author/Source & Resolution & PNW Climate \\
\hline $\begin{array}{l}\text { MIROC } 3.2 \\
\text { (medres) }\end{array}$ & $\begin{array}{l}\text { CCSR/NIES/FRCGC, Japan } \\
\text { CCSR = Center for Climate System } \\
\text { Research, University of Tokyo, } \\
\text { NIES = National Institute for } \\
\text { Environmental Studies, FRCGC = } \\
\text { Frontier Research Center for Global } \\
\text { Chance, Japan Agency for Marine- } \\
\text { Earth Science and Technology } \\
\text { (JAMSTEC) }\end{array}$ & $\sim 2.8^{\circ} \times 2.8^{\circ}$ & $\begin{array}{l}\text { Wet and warmer } \\
\text { winter Projections }\end{array}$ \\
\hline CCSM3 & $\begin{array}{l}\text { Community Climate System Model } \\
\text { developed by National Center for } \\
\text { Atmospheric Research (NCAR), } \\
\text { USA }\end{array}$ & $1.4^{\circ} \times 1.4^{\circ}$ & \\
\hline IPSL-CM4 & $\begin{array}{l}\text { Institut Pierre Simon Laplace } \\
\text { (IPSL), CNRS, CEA, France }\end{array}$ & $2.5^{\circ} \times 3.75^{\circ}$ & Wetter winter \\
\hline $\begin{array}{l}\text { UKMO- } \\
\text { HadCM3 }\end{array}$ & $\begin{array}{l}\text { Hadley Centre for Climate } \\
\text { Prediction and Research, Met } \\
\text { Office, United Kingdom }\end{array}$ & $2.5^{\circ} \times 3.75^{\circ}$ & $\begin{array}{l}\text { Warmer and Drier } \\
\text { Summer }\end{array}$ \\
\hline PCM & $\begin{array}{l}\text { National Center for Atmospheric } \\
\text { Research (NCAR) }\end{array}$ & $\sim 2.8^{\circ} \times 2.8^{\circ}$ & $\begin{array}{l}\text { Cooler and Drier } \\
\text { Summer }\end{array}$ \\
\hline
\end{tabular}


Table 2 (a). Calibration of the SWAT model using Sequential Uncertainty Fitting algorithm to obtain the optimum parameters representing the basin characteristics for four calibration sites (Lucky Peak, Arrowrock, Anderson Ranch, Twin Springs) in the Boise River Basin.

\begin{tabular}{|c|c|c|c|c|c|c|c|c|c|}
\hline \multirow[b]{2}{*}{$\begin{array}{c}\text { Parameter } \\
\text { name }\end{array}$} & \multirow[b]{2}{*}{ Parameter definition:Parma } & \multirow[b]{2}{*}{$\begin{array}{c}\text { low } \\
\text { bound }\end{array}$} & \multirow[b]{2}{*}{$\begin{array}{c}\text { up } \\
\text { bound }\end{array}$} & \multirow[b]{2}{*}{ imet } & \multicolumn{4}{|c|}{ Calibration Sites } & \multirow[b]{2}{*}{ scale level } \\
\hline & & & & & $\begin{array}{l}\text { Lucky } \\
\text { Peak }\end{array}$ & $\begin{array}{c}\text { Arrowr } \\
\text { ock }\end{array}$ & $\begin{array}{c}\text { Twin } \\
\text { Springs }\end{array}$ & $\begin{array}{c}\text { Anderson } \\
\text { Ranch }\end{array}$ & \\
\hline Canmx & Maximum canopy storage (mm) & 0.816 & 9.802 & $\mathrm{~V}$ & 4.344 & 3.109 & 2.508 & 8.351 & hru \\
\hline $\operatorname{Cn} 2$ & Initial SCS CN II value & -34.77 & 37.44 & $\mathrm{r}$ & -32.5 & -21 & -32.9 & -21.68 & hru \\
\hline Alpha_Bf & baseflow alpha factor (days) & 0 & 1 & $\mathrm{~V}$ & & & & & hru \\
\hline Epco & Plant uptake compensation factor & -50 & 50 & $\mathrm{r}$ & & & & & hru \\
\hline Esco & Soil evaporation compensation factor & 0.95 & 1 & $\mathrm{~V}$ & & & & & hru \\
\hline Gw_Delay & Groundwater delay (days) & 0 & 192.3 & $\mathrm{~V}$ & & & & & hru \\
\hline Gw_Revap & Groundwater revap coefficient & 0.02 & 0.2 & $\mathrm{v}$ & & & & & hru \\
\hline Revapmn & $\begin{array}{l}\text { Threshold water depth in the shallow aquifer } \\
\text { for "revap" (mm) }\end{array}$ & 0.01 & 500 & $\mathrm{v}$ & & & & & hru \\
\hline Gwqmn & $\begin{array}{l}\text { Threshold water depth in the shallow aquifer } \\
\text { for flow }(\mathrm{mm})\end{array}$ & 0 & 673 & $\mathrm{v}$ & 572.2 & 422.3 & 535.5 & 75.5 & hru \\
\hline Rchrg_Dp & Deep aquifer percolation fraction & 0 & 1 & $\mathrm{~V}$ & 0.488 & 0.89 & 0.364 & 0.272 & hru \\
\hline $\mathrm{Ch} \_\mathrm{K} 2$ & $\begin{array}{l}\text { channel effective hydraulic conductivity } \\
(\mathrm{mm} / \mathrm{hr})\end{array}$ & 3.8 & 80.8 & $\mathrm{v}$ & 19.8 & 72.3 & 51.01 & 34.2 & subbasin \\
\hline Sol_Awc & Available water capacity (mm H2O/mm soil) & -50 & 50 & $\mathrm{r}$ & 8.9 & 16.9 & 12.38 & 13.9 & hru \\
\hline Sol_K & Saturated hydraulic conductivity $(\mathrm{mm} / \mathrm{hr})$ & 12.5 & 37.5 & $\mathrm{r}$ & & & & & hru \\
\hline Surlag & surface runoff lag time (days) & 0 & 10 & $\mathrm{~V}$ & \multicolumn{4}{|c|}{1.446} & basin \\
\hline Timp & Snow pack temperature lag factor & 0.001 & 1 & $\mathrm{v}$ & \multicolumn{4}{|c|}{0.0063} & basin \\
\hline Smtmp & snow melt base temperature $(\mathrm{C})$ & 1.8 & 5.5 & $\mathrm{v}$ & \multicolumn{4}{|c|}{4.1} & basin \\
\hline & note: for imet, $\mathrm{v}$ - replacement, $\mathrm{r}$ - & al & by & de & & & & & \\
\hline
\end{tabular}


Table 2 (b). Calibration of the SWAT model using Sequential Uncertainty Fitting algorithm to obtain the optimum parameters representing the basin characteristics for Parma in the Boise River Basin.

\begin{tabular}{|c|c|c|c|c|c|c|}
\hline $\begin{array}{l}\text { Parameter } \\
\text { name }\end{array}$ & Parameter definition & $\begin{array}{c}\text { low } \\
\text { bound }\end{array}$ & up & imet & $\begin{array}{c}\text { Parma } \\
\text { Calibrat } \\
\text { ion } \\
\text { values }\end{array}$ & scale level \\
\hline Canmx & Maximum canopy storage $(\mathrm{mm})$ & 0.816 & 9.802 & $\mathrm{v}$ & 1.705 & hru \\
\hline $\mathrm{Cn} 2$ & Initial SCS CNN II value & -34.77 & 37.44 & $\mathrm{r}$ & 23.6 & hru \\
\hline Alpha_Bf & baseflow alpha factor (days) & 0 & 1 & $\mathrm{v}$ & 0.0601 & hrut \\
\hline Epco & Plant uptake compensation factor & -50 & 50 & $\mathrm{r}$ & 9.46 & hru \\
\hline Esco & Soil evaporation compensation factor & 0.95 & 1 & $\mathrm{v}$ & 0.962 & hrut \\
\hline Gw_Delay & Groundwater delay (days) & 0 & 192.3 & $\mathrm{v}$ & 173.2 & hrut \\
\hline Gw_Revap & Groundwater revap coefficient & 0.02 & 0.2 & $\mathrm{v}$ & 0.191 & hru \\
\hline Revapmn & $\begin{array}{l}\text { Threshold water depth in the shallow aquifer } \\
\text { for "revap" ( } \mathrm{mm} \text { ) }\end{array}$ & 0.01 & 500 & $\mathrm{v}$ & 3.66 & hru \\
\hline Gwqmn & $\begin{array}{l}\text { Threshold water depth in the shallow aquifer } \\
\text { for flow (mm) }\end{array}$ & 0 & 673 & $\mathrm{v}$ & 643.9 & hrut \\
\hline Rchrg_Dp & Deep aquifer percolation fraction & 0 & 1 & $\mathrm{v}$ & 0.252 & hru \\
\hline Ch_K2 & $\begin{array}{l}\text { channel effective hydraulic conductivity } \\
(\mathrm{mm} / \mathrm{hr})\end{array}$ & 3.8 & 80.8 & $\mathrm{v}$ & 13.36 & subbasin \\
\hline Sol_Awc & Available water capacity ( $\mathrm{mm} \mathrm{H} 2 \mathrm{O} / \mathrm{mm}$ soil) & -50 & 50 & $r$ & -28.88 & hru \\
\hline Sol_K & Saturated hydraulic conductivity (mm/hr) & 12.5 & 37.5 & $\mathrm{r}$ & 36.73 & hru \\
\hline Surlag & surface runoff lag time (days) & 0 & 10 & $\mathrm{v}$ & 1.446 & basin \\
\hline Timp & Snow pack temperature lag factor & 0.001 & 1 & $\mathrm{v}$ & 0.0063 & basin \\
\hline Smtmp & snow melt base temperature (C) & 1.8 & 5.5 & $\mathrm{v}$ & 4.1 & basin \\
\hline & \multicolumn{6}{|c|}{ note: for imet, $\mathrm{v}$ - replacement, $\mathrm{r}$ - multiplying initial value by value (in percentage) } \\
\hline
\end{tabular}


Table 3. Calibration and Validation statistics for various gaging locations in the Boise River Basin.

\begin{tabular}{|c|c|c|c|}
\hline Subbasin & & $r^{2}$ & NSE \\
\hline \multirow{2}{*}{ Parma } & calibrated $(1959-1963)$ & 0.81 & 0.75 \\
\hline & validated (1964 - 2004) & 0.82 & 0.80 \\
\hline \multirow{2}{*}{ Lucky Peak } & calibrated (1959 - 1963) & 0.79 & 0.78 \\
\hline & validated (1964 - 2004) & 0.78 & 0.73 \\
\hline \multirow{2}{*}{ Arrow Rock } & calibrated $(1959-1963)$ & 0.75 & 0.75 \\
\hline & validated (1964 - 2004) & 0.77 & 0.70 \\
\hline \multirow{2}{*}{ Twin Spring } & calibrated (1959 - 1963) & 0.87 & 0.85 \\
\hline & validated (1964 - 2004) & 0.81 & 0.65 \\
\hline \multirow{2}{*}{ Anderson Ranch } & calibrated (1959 - 1963) & 0.87 & 0.70 \\
\hline & validated (1964 - 2004) & 0.83 & 0.64 \\
\hline
\end{tabular}


This is an author-produced, peer-reviewed version of this article. The final, definitive version of this document can be found online at $J A W R A$ : Journal of the American Water Resources Association, published by Wiley-Blackwell. Copyright restrictions may apply. The definitive version is available at www.blackwell-synergy.com. DOI: 10.1111/j.1752-1688.2011.00605.x

Table 4. Calibration of the SWAT model using Sequential Uncertainty Fitting algorithm to obtain the optimum parameters representing the basin characteristics in the Spokane River Basin.

\begin{tabular}{|c|c|c|c|c|c|c|c|}
\hline \multirow[b]{2}{*}{$\begin{array}{c}\text { Parameter } \\
\text { name }\end{array}$} & \multirow[b]{2}{*}{ Parameter definition:Parma } & \multirow[b]{2}{*}{$\begin{array}{c}\text { low } \\
\text { bound }\end{array}$} & \multirow[b]{2}{*}{ up bound } & \multirow[b]{2}{*}{ imet } & \multicolumn{2}{|c|}{ Calibration Sites } & \multirow[b]{2}{*}{ scale level } \\
\hline & & & & & Post Falls & $\begin{array}{l}\text { Spokane to } \\
\text { Post Falls }\end{array}$ & \\
\hline Alpha Bf & baseflow alpha factor (days) & 0.05 & 0.15 & $\mathrm{~V}$ & 0.077 & 0.079 & hru \\
\hline Canmx & Maximum canopy storage (mm) & 1.28 & 3.84 & $\mathrm{~V}$ & 2.7 & 1.8 & hru \\
\hline $\mathrm{Ch \_ K2}$ & channel effective hydraulic conductivity $(\mathrm{mm} / \mathrm{hr})$ & 10 & 30 & $\mathrm{~V}$ & 31.5 & 19.9 & subbasin \\
\hline $\mathrm{Cn} 2$ & Initial SCS CN II value & 6.38 & 19.14 & $\mathrm{r}$ & 7.78 & 12.9 & hru \\
\hline Epco & Plant uptake compensation factor & -50 & 50 & $\mathrm{r}$ & 16.1 & -37.4 & hru \\
\hline Esco & Soil evaporation compensation factor & 0.33 & 1 & $\mathrm{~V}$ & 0.55 & 0.9 & hru \\
\hline Gw Delay & Groundwater delay (days) & 101 & 303 & $\mathrm{~V}$ & 188.4 & 146.7 & hru \\
\hline Gw_Revap & Groundwater revap coefficient & 0.047 & 0.141 & $\mathrm{~V}$ & 0.093 & 0.133 & hru \\
\hline Gwqmn & Threshold water depth in the shallow aquifer for flow (mm) & 219 & 656 & $\mathrm{~V}$ & 333.8 & 299.2 & hru \\
\hline Revapmn & Threshold water depth in the shallow aquifer for "revap" (mm) & 0.01 & 500 & $\mathrm{~V}$ & 299.1 & 146.9 & hru \\
\hline Sol_Awc & Available water capacity (mm H20/mm soil) & 12.5 & 37.5 & $\mathrm{r}$ & 18.6 & 33.3 & hru \\
\hline Sol_K & Saturated hydraulic conductivity $(\mathrm{mm} / \mathrm{hr})$ & 4.27 & 12.8 & $\mathrm{r}$ & 5.7 & 13.2 & hru \\
\hline Surlag & surface runoff lag time (days) & 2.27 & 6.81 & $\mathrm{~V}$ & \multicolumn{2}{|c|}{6.3} & basin \\
\hline Timp & Snow pack temperature lag factor & 0.01 & 1 & $\mathrm{~V}$ & \multicolumn{2}{|c|}{0.0035} & basin \\
\hline \multirow[t]{2}{*}{ Smtmp } & snow melt base temperature (C) & 1.61 & 4.83 & $\mathrm{~V}$ & \multicolumn{2}{|c|}{3.39} & basin \\
\hline & \multicolumn{3}{|c|}{ note: for imet, $\mathrm{v}$ - replacement, $\mathrm{r}$ - multiplying initial value by value (in percentage) } & & & & \\
\hline
\end{tabular}


This is an author-produced, peer-reviewed version of this article. The final, definitive version of this document can be found online at JAWRA: Journal of the American Water Resources Association, published by Wiley-Blackwell. Copyright restrictions may apply. The definitive version is available at www.blackwell-synergy.com. DOI: 10.1111/j.1752-1688.2011.00605.x

Table 5. Calibration and Validation statistics for various gaging locations in the the Spokane River Basin

\begin{tabular}{|c|c|c|c|c|}
\hline Subbasin & Gage station & & $r^{2}$ & NSE \\
\hline \multirow{3}{*}{ Post Falls } & \multirow{3}{*}{ Post Falls, ID, 12419000} & calibrated $(1978-1980)$ & 0.76 & 0.58 \\
\hline & & validated (1953 -1977) & 0.72 & 0.65 \\
\hline & & validated (1981 -1999) & 0.66 & 0.48 \\
\hline \multirow{3}{*}{ Spokane } & \multirow{3}{*}{ Spokane, WA, 12422500} & calibrated $(1978-1980)$ & 0.75 & 0.55 \\
\hline & & validated $(1953-1977)$ & 0.71 & 0.62 \\
\hline & & validated (1981 -1999) & 0.66 & 0.41 \\
\hline
\end{tabular}


This is an author-produced, peer-reviewed version of this article. The final, definitive version of this document can be found online at JAWRA: Journal of the American Water Resources Association, published by Wiley-Blackwell. Copyright restrictions may apply. The definitive version is available at www.blackwell-synergy.com. DOI: 10.1111/j.1752-1688.2011.00605.x

Table 6. (a) The Boise River Basin Future Temperature and Precipitation changes for each decade between 2010-2060 for each scenario (A2, A1b and B1) (b) The Spokane River Basin Future Temperature and Precipitation changes for each decade between 2010-2060 for each scenario (A2, A1B and B1)

\begin{tabular}{|c|c|c|c|}
\hline \multicolumn{4}{|l|}{ A2 } \\
\hline & & $\mathbf{P}(\%)$ & $\mathrm{T}\left(\mathrm{C}^{\circ}\right)$ \\
\hline 2010-2019 & $\operatorname{ccs} m 3 \_0$ & 2.49 & 1.63 \\
\hline & hadcm 3 & 3.60 & 0.76 \\
\hline & ipsl_cm4 & 15.71 & 1.11 \\
\hline & miroc3_2_medres & 9.09 & 1.64 \\
\hline & $\mathrm{pcm} 1$ & -6.02 & 0.02 \\
\hline $2020-2029$ & $\operatorname{ccs} m 3 \_0$ & 0.93 & 1.98 \\
\hline & hadcm 3 & 3.76 & 1.35 \\
\hline & ipsl_cm4 & 9.72 & 1.53 \\
\hline & miroc3_2_medres & -2.33 & 1.24 \\
\hline & $\mathrm{pcm} 1$ & 6.36 & 0.93 \\
\hline $2030-2039$ & $\operatorname{ccs} m 3 \_0$ & -1.82 & 2.47 \\
\hline & hadcm3 & -0.47 & 1.48 \\
\hline & ipsl_cm4 & 17.66 & 2.11 \\
\hline & miroc3_2_medres & 8.23 & 2.47 \\
\hline & $\mathrm{pcm} 1$ & 3.33 & 0.77 \\
\hline 2040-2049 & $\operatorname{ccs} m 3 \_0$ & 8.22 & 2.63 \\
\hline & hadcm 3 & 0.85 & 2.59 \\
\hline & ipsl_cm4 & 34.37 & 2.43 \\
\hline & miroc3_2_medres & -1.64 & 3.17 \\
\hline & $\mathrm{pcm} 1$ & 7.15 & 1.47 \\
\hline 2050-2059 & $\operatorname{ccs} m 3{ }_{3} 0$ & 4.89 & 3.37 \\
\hline & hadcm3 & 7.00 & 2.61 \\
\hline & ipsl_cm4 & 36.28 & 3.61 \\
\hline & miroc3 2 medres & 1.00 & 3.34 \\
\hline & $\mathrm{pcm} 1$ & 1.69 & 1.77 \\
\hline
\end{tabular}

\begin{tabular}{|c|c|c|c|}
\hline \multicolumn{4}{|l|}{ A1B } \\
\hline & & $P(\%)$ & $\mathrm{T}\left(\mathrm{C}^{\circ}\right)$ \\
\hline \multirow{5}{*}{\begin{tabular}{|l|}
$2010-2019$ \\
\end{tabular}} & $\operatorname{ccs} 33 \_0$ & 0.18 & 1.38 \\
\hline & hadcm 3 & -1.19 & 1.76 \\
\hline & ipsl_cm4 & 17.89 & 1.56 \\
\hline & miroc3_2_medres & -9.11 & 1.07 \\
\hline & $\mathrm{pcm} 1$ & 14.12 & 0.79 \\
\hline \multirow[t]{5}{*}{$2020-2029$} & ccsm3_0 & 1.45 & 2.05 \\
\hline & hadcm 3 & 3.20 & 1.96 \\
\hline & ipsl_cm4 & 25.16 & 1.85 \\
\hline & miroc3_2_medres & -9.06 & 1.98 \\
\hline & $\mathrm{pcm} 1$ & -8.81 & 1.10 \\
\hline \multirow[t]{5}{*}{ 2030-2039 } & ccsm3_0 & -7.66 & 2.02 \\
\hline & hadcm 3 & 4.58 & 2.10 \\
\hline & ipsl_cm4 & 19.82 & 2.48 \\
\hline & miroc3_2_medres & 6.40 & 2.78 \\
\hline & $\mathrm{pcm} 1$ & -8.50 & 1.45 \\
\hline \multirow[t]{5}{*}{ 2040-2049 } & ccsm3_0 & -5.62 & 3.08 \\
\hline & hadcm 3 & 14.86 & 2.80 \\
\hline & ipsl_cm4 & 35.15 & 2.99 \\
\hline & miroc3_2_medres & 4.06 & 3.06 \\
\hline & $\mathrm{pcm} 1$ & -1.59 & 1.95 \\
\hline \multirow[t]{5}{*}{$2050-2059$} & $\operatorname{ccs} 33{ }_{3} 0$ & 1.06 & 3.44 \\
\hline & hadcm 3 & 3.15 & 3.22 \\
\hline & ipsl_cm4 & 21.28 & 3.70 \\
\hline & miroc3_2_medres & 6.05 & 3.91 \\
\hline & pcm1 & 5.49 & 2.59 \\
\hline
\end{tabular}

\begin{tabular}{|c|c|c|c|}
\hline \multicolumn{4}{|l|}{ B1 } \\
\hline & & $\mathbf{P}(\%)$ & $T\left(C^{\circ}\right)$ \\
\hline \multirow[t]{5}{*}{\begin{tabular}{|l|}
$2010-2019$ \\
\end{tabular}} & ccsm3_0 & 7.02 & 1.690 \\
\hline & hadcm 3 & 3.79 & 1.005 \\
\hline & ipsl_cm4 & 16.97 & 1.321 \\
\hline & miroc3_2_medres & -6.58 & 1.418 \\
\hline & pcm1 & 13.15 & 0.484 \\
\hline \multirow[t]{5}{*}{$2020-2029$} & ccsm3_0 & -3.45 & 1.470 \\
\hline & hadcm 3 & 9.17 & 1.567 \\
\hline & ipsl_cm4 & 16.28 & 1.645 \\
\hline & miroc3_2_medres & 6.10 & 1.345 \\
\hline & pcm1 & 18.17 & 0.699 \\
\hline \multirow[t]{5}{*}{$2030-2039$} & ccsm3_0 & -6.72 & 1.302 \\
\hline & hadcm 3 & 6.21 & 1.587 \\
\hline & ipsl_cm4 & 14.66 & 2.063 \\
\hline & miroc3_2_medres & 4.37 & 2.101 \\
\hline & $\mathrm{pcm} 1$ & 12.15 & 0.696 \\
\hline \multirow[t]{5}{*}{ 2040-2049 } & ccsm3_0 & 3.62 & 2.003 \\
\hline & hadcm 3 & 16.88 & 2.067 \\
\hline & ipsl_cm4 & 30.49 & 2.702 \\
\hline & miroc3_2_medres & -2.24 & 2.907 \\
\hline & $\mathrm{pcm} 1$ & 16.28 & 0.747 \\
\hline \multirow[t]{5}{*}{$2050-2059$} & ccsm3_0 & 0.46 & 2.068 \\
\hline & hadcm 3 & 2.89 & 2.865 \\
\hline & ipsl_cm4 & 25.75 & 2.542 \\
\hline & miroc3_2_medres & -1.17 & 3.092 \\
\hline & $\mathrm{pcm} 1$ & 9.28 & 0.9 \\
\hline
\end{tabular}

(a)

\begin{tabular}{|c|c|c|c|}
\hline \multicolumn{4}{|l|}{ A2 } \\
\hline & & $\mathrm{P}[\%]$ & $\mathrm{T}\left(\mathrm{C}^{\circ}\right)$ \\
\hline \multirow[t]{5}{*}{ 2010-2019 } & $\operatorname{ccs} m 3 \_0$ & 2.10 & 1.654 \\
\hline & hadcm 3 & 3.18 & 0.727 \\
\hline & ipsl_cm4 & 10.28 & 0.896 \\
\hline & miroc3_2_medres & 4.62 & 1.512 \\
\hline & pcm1 & 1.97 & 0.100 \\
\hline \multirow[t]{5}{*}{$2020-2029$} & $\operatorname{ccs} m 3 \_0$ & 5.45 & 1.849 \\
\hline & hadcm 3 & 4.12 & 1.034 \\
\hline & ipsl_cm4 & 4.18 & 1.377 \\
\hline & miroc3_2_medres & 7.80 & 1.128 \\
\hline & $\mathrm{pcm} 1$ & -2.02 & 0.888 \\
\hline \multirow[t]{5}{*}{ 2030-2039 } & $\operatorname{ccs} m 3 \_0$ & 3.37 & 2.187 \\
\hline & hadcm 3 & 4.45 & 1.327 \\
\hline & ipsl_cm4 & 1.52 & 1.947 \\
\hline & miroc3_2_medres & 8.32 & 2.101 \\
\hline & $\mathrm{pcm} 1$ & 0.76 & 0.749 \\
\hline \multirow[t]{5}{*}{ 2040-2049 } & $\operatorname{ccs} m 3 \_0$ & 6.32 & 2.332 \\
\hline & hadcm 3 & -3.80 & 2.300 \\
\hline & ipsl_cm4 & 14.46 & 2.248 \\
\hline & miroc3_2_medres & 5.66 & 2.607 \\
\hline & $\mathrm{pcm} 1$ & 5.58 & 1.499 \\
\hline \multirow[t]{5}{*}{ 2050-2059 } & $\operatorname{ccs} m 3 \_0$ & 0.39 & 2.961 \\
\hline & hadcm 3 & 10.09 & 2.265 \\
\hline & ipsl_cm4 & 8.17 & 3.189 \\
\hline & miroc3_2_medres & 6.37 & 3.002 \\
\hline & pcm1 & 3.15 & 1.809 \\
\hline
\end{tabular}

\begin{tabular}{|c|c|c|c|}
\hline \multirow[t]{2}{*}{ A1B } & & & \\
\hline & & $\mathbf{P}(\%)$ & $\mathrm{T}\left(\mathrm{C}^{\circ}\right)$ \\
\hline \multirow[t]{5}{*}{$2010-2019$} & ccsm3_0 & 2.40 & 1.180 \\
\hline & hadcm 3 & -0.97 & 1.714 \\
\hline & ipsl_cm4 & 3.46 & 1.301 \\
\hline & miroc3_2 & 1.36 & 0.829 \\
\hline & $\mathrm{pcm} 1$ & 5.80 & 0.844 \\
\hline \multirow[t]{5}{*}{$2020-2029$} & ccsm3_0 & 6.94 & 1.713 \\
\hline & hadcm 3 & 5.26 & 1.924 \\
\hline & ipsl_cm4 & 8.71 & 1.736 \\
\hline & miroc3_2 & -1.21 & 1.681 \\
\hline & $\mathrm{pcm} 1$ & -6.69 & 0.951 \\
\hline \multirow[t]{5}{*}{$2030-2039$} & ccsm3_0 & 4.31 & 1.879 \\
\hline & hadcm 3 & 12.36 & 1.893 \\
\hline & ipsl_cm4 & 10.25 & 2.214 \\
\hline & miroc3_2 & 10.64 & 2.529 \\
\hline & $\mathrm{pcm} 1$ & -6.15 & 1.364 \\
\hline \multirow[t]{5}{*}{$2040-2049$} & ccsm3_0 & -4.00 & 3.025 \\
\hline & hadcm 3 & 9.15 & 2.786 \\
\hline & ipsl_cm4 & 14.84 & 2.582 \\
\hline & miroc3_2 & 13.02 & 2.592 \\
\hline & pcml & -2.57 & 1.986 \\
\hline \multirow[t]{5}{*}{$2050-2059$} & ccsm3_0 & 7.21 & 2.984 \\
\hline & hadcm 3 & 8.73 & 3.241 \\
\hline & ipsl_cm4 & 12.45 & 3.530 \\
\hline & miroc3_2 & 17.89 & 3.253 \\
\hline & $\mathrm{pcm} 1$ & 2.15 & 2.305 \\
\hline
\end{tabular}

\begin{tabular}{|l|l|r|r|}
\hline B1 & & & \\
\hline B1 & & P $(\%)$ & \multicolumn{1}{|c|}{$\left(\mathbf{C}^{\circ}\right)$} \\
\hline $2010-2019$ & ccsm3_0 & 6.86 & 1.650 \\
\hline & hadcm3 & 6.48 & 0.914 \\
\hline & ipsl_cm4 & 4.78 & 1.413 \\
\hline & miroc3_2 & 3.00 & 1.087 \\
\hline & pcm1 & 6.75 & 0.335 \\
\hline $2020-2029$ & ccsm3_0 & -2.59 & 1.017 \\
\hline & hadcm3 & 3.60 & 1.587 \\
\hline & ipsl_cm4 & 7.26 & 1.621 \\
\hline & miroc3_2 & 7.75 & 1.218 \\
\hline & pcm1 & 5.18 & 0.635 \\
\hline $2030-2039$ & ccsm3_0 & 0.28 & 1.295 \\
\hline & hadcm3 & 6.05 & 1.600 \\
\hline & ipsl_cm4 & -7.39 & 1.822 \\
\hline & miroc3_2 & 10.58 & 1.913 \\
\hline & pcm1 & 5.29 & 0.542 \\
\hline & ccsm3_0 & 5.00 & 1.874 \\
\hline $2040-2049$ & hadcm3 & 11.68 & 1.923 \\
\hline & ipsl_cm4 & 14.16 & 2.542 \\
\hline & miroc3_2 & 8.90 & 2.606 \\
\hline & pcm1 & 11.41 & 0.877 \\
\hline & ccsm3_0 & 1.27 & 1.915 \\
\hline & hadcm3 & -1.25 & 2.699 \\
\hline & ipsl_cm4 & 8.00 & 2.392 \\
\hline & miroc3_2 & 14.31 & 2.722 \\
\hline & pcm1 & 7.34 & 0.840 \\
\hline & & & \\
\hline & & & \\
\hline & &
\end{tabular}




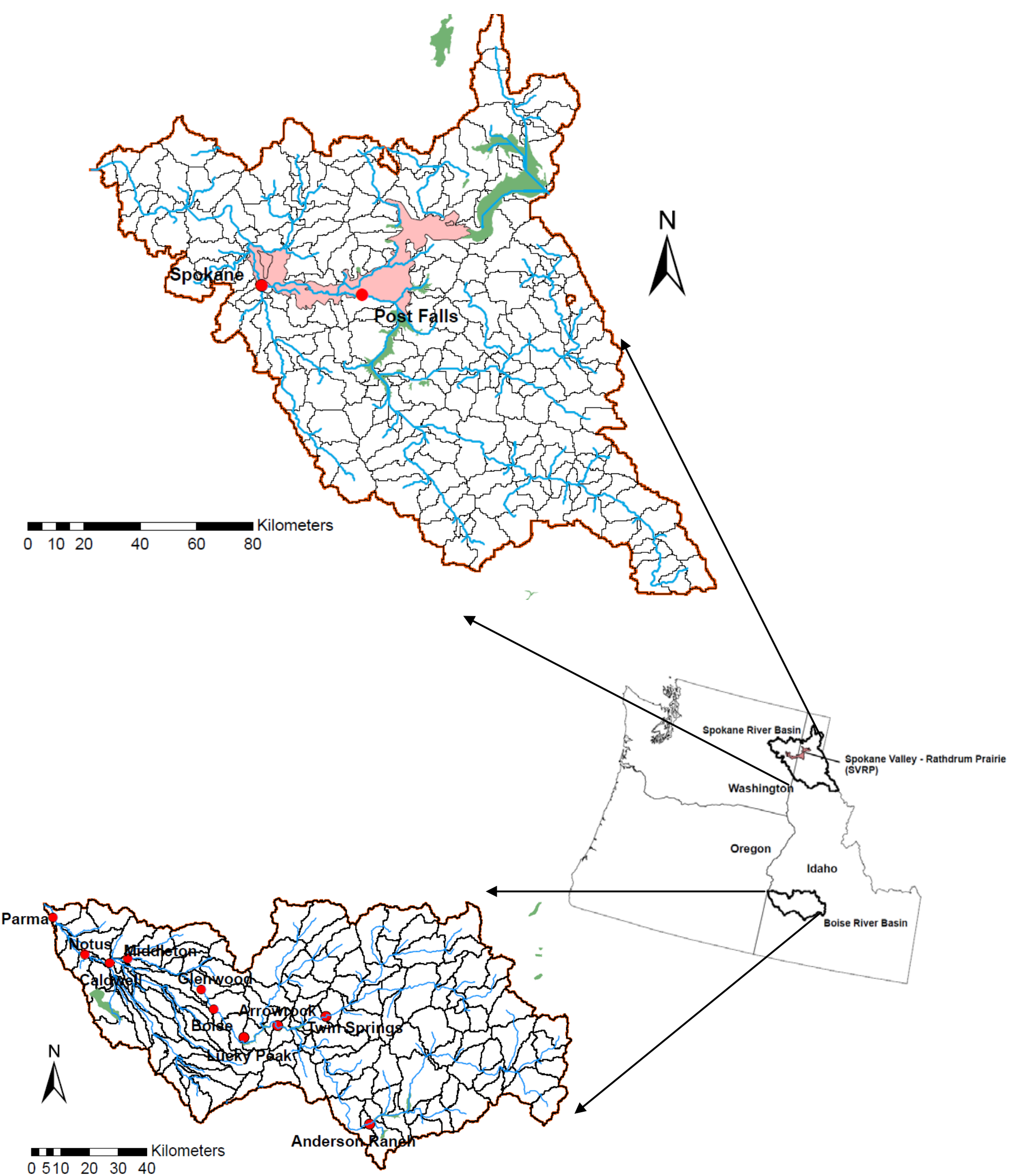

Figure 1 
This is an author-produced, peer-reviewed version of this article. The final, definitive version of this document can be found online at JAWRA: Journal of the American Water Resources Association, published by Wiley-Blackwell. Copyright restrictions may apply. The definitive version is available at www.blackwell-synergy.com. DOI: 10.1111/j.1752-1688.2011.00605.x
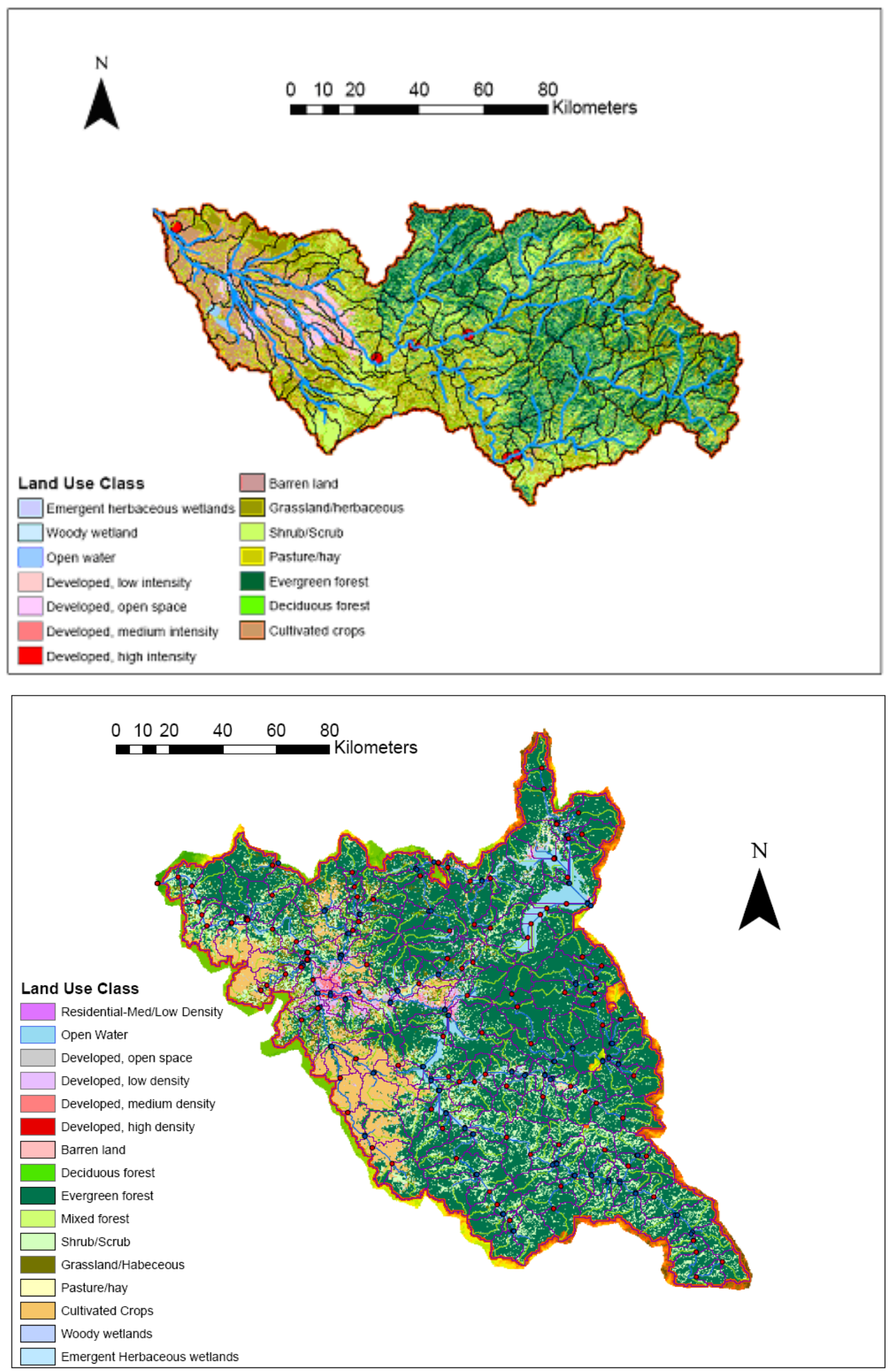

Figure 2 
This is an author-produced, peer-reviewed version of this article. The final, definitive version of this document can be found online at JAWRA: Journal of the American Water Resources Association, published by Wiley-Blackwell. Copyright restrictions may apply. The definitive version is available at www.blackwell-synergy.com. DOI: 10.1111/j.1752-1688.2011.00605.x

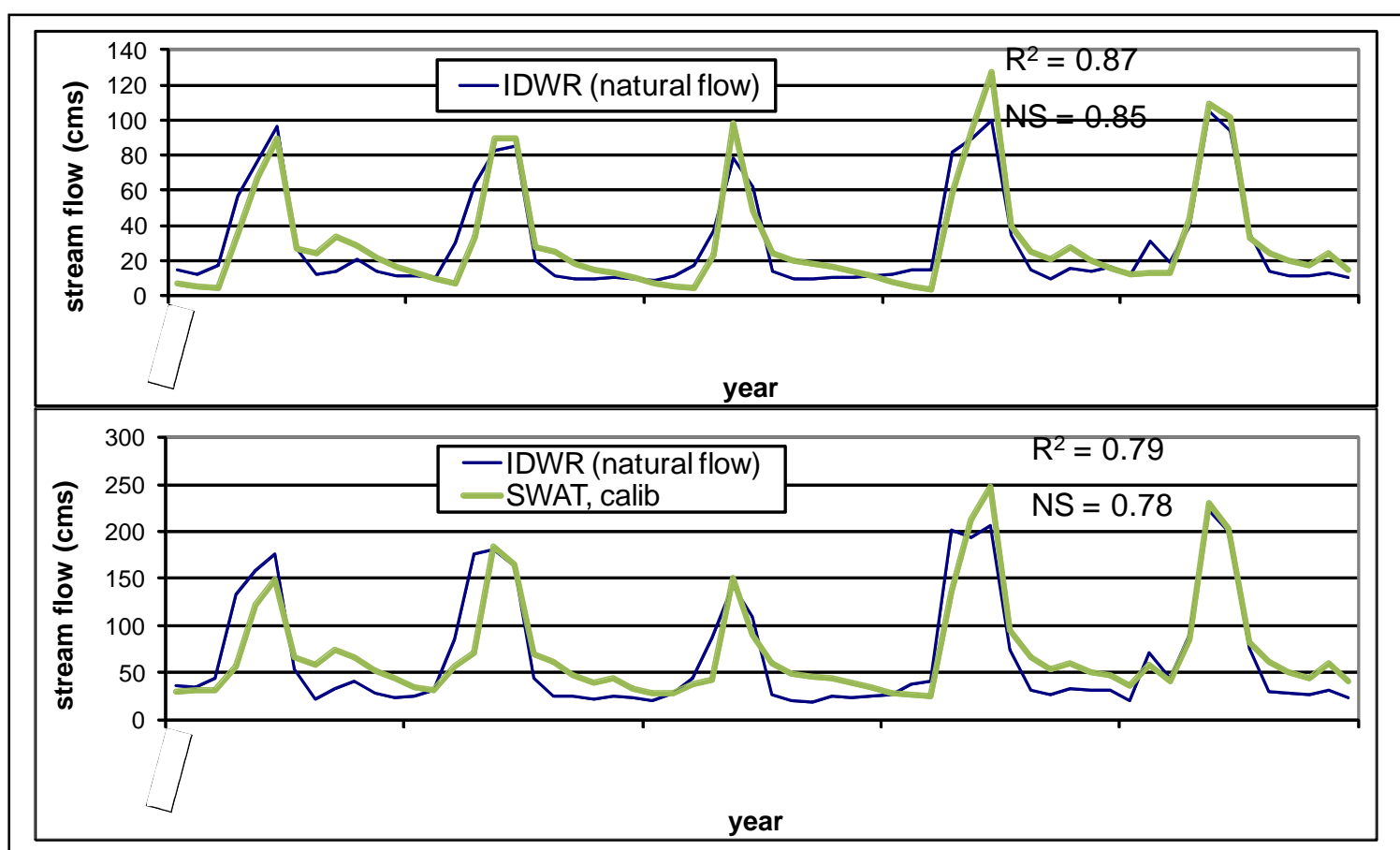

(a)

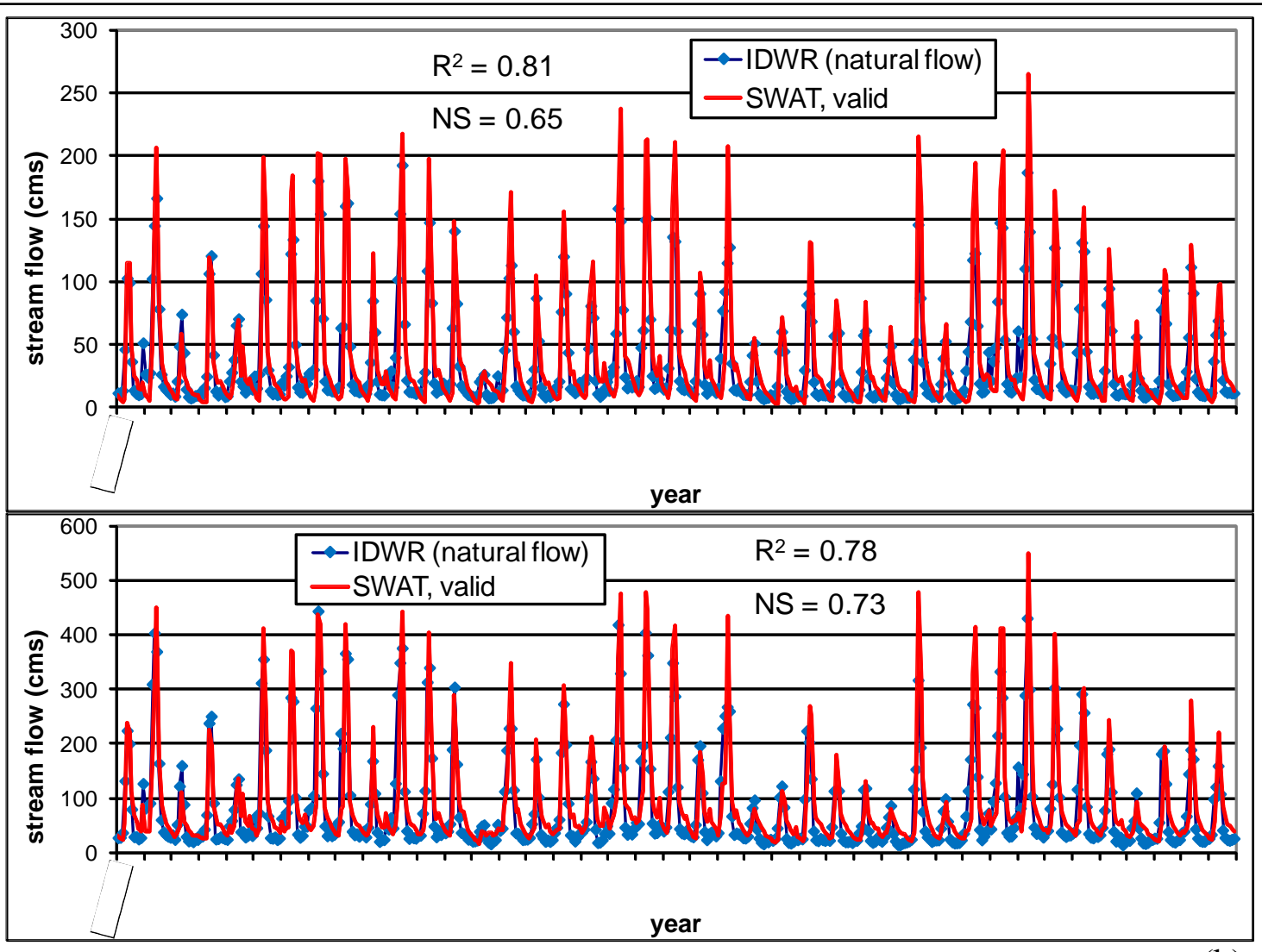

(b)

Figure 3 
This is an author-produced, peer-reviewed version of this article. The final, definitive version of this document can be found online at JAWRA: Journal of the American Water Resources Association, published by Wiley-Blackwell. Copyright restrictions may apply. The definitive version is available at www.blackwell-synergy.com. DOI: 10.1111/j.1752-1688.2011.00605.x
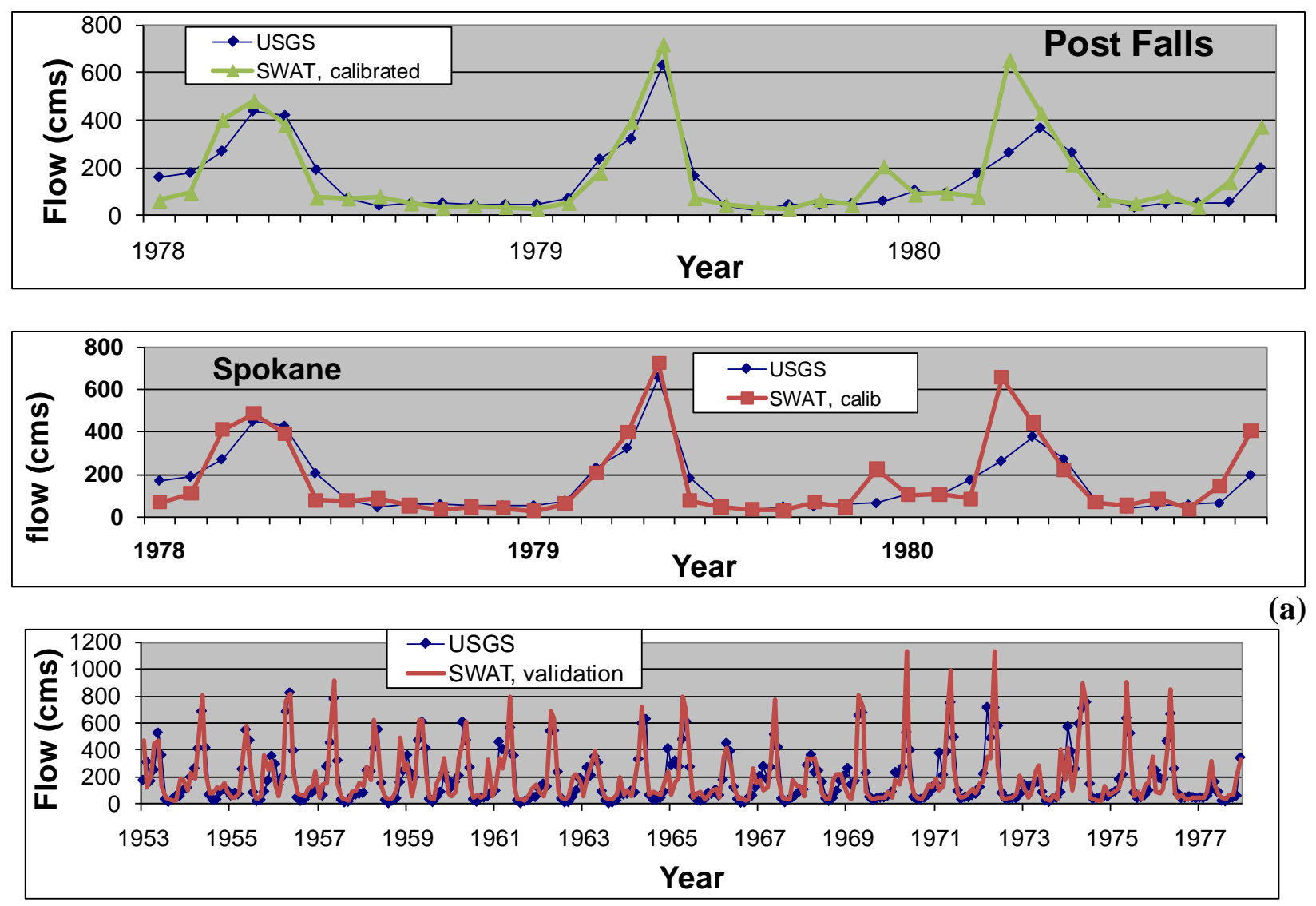

(a)

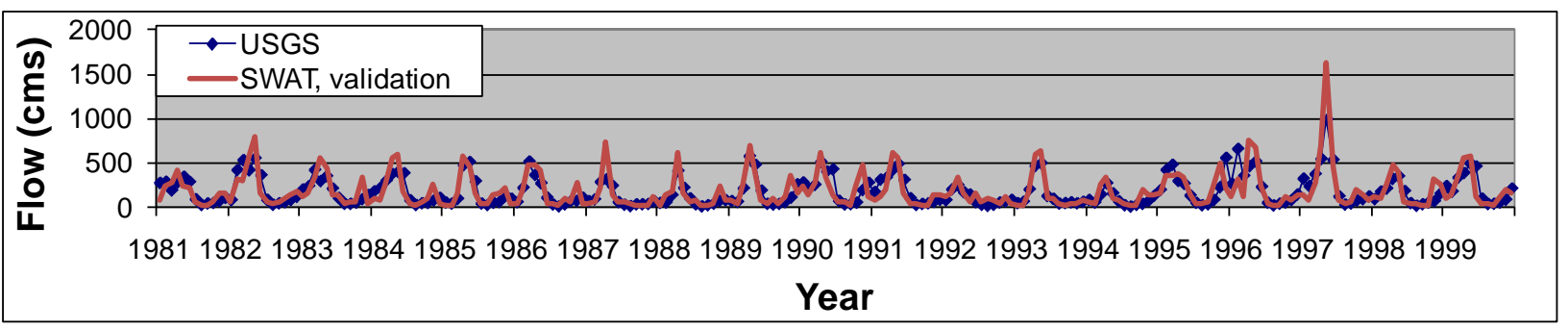


This is an author-produced, peer-reviewed version of this article. The final, definitive version of this document can be found online at JAWRA: Journal of the American Water Resources Association, published by Wiley-Blackwell. Copyright restrictions may apply. The definitive version is available at www.blackwell-synergy.com. DOI: 10.1111/j.1752-1688.2011.00605.x
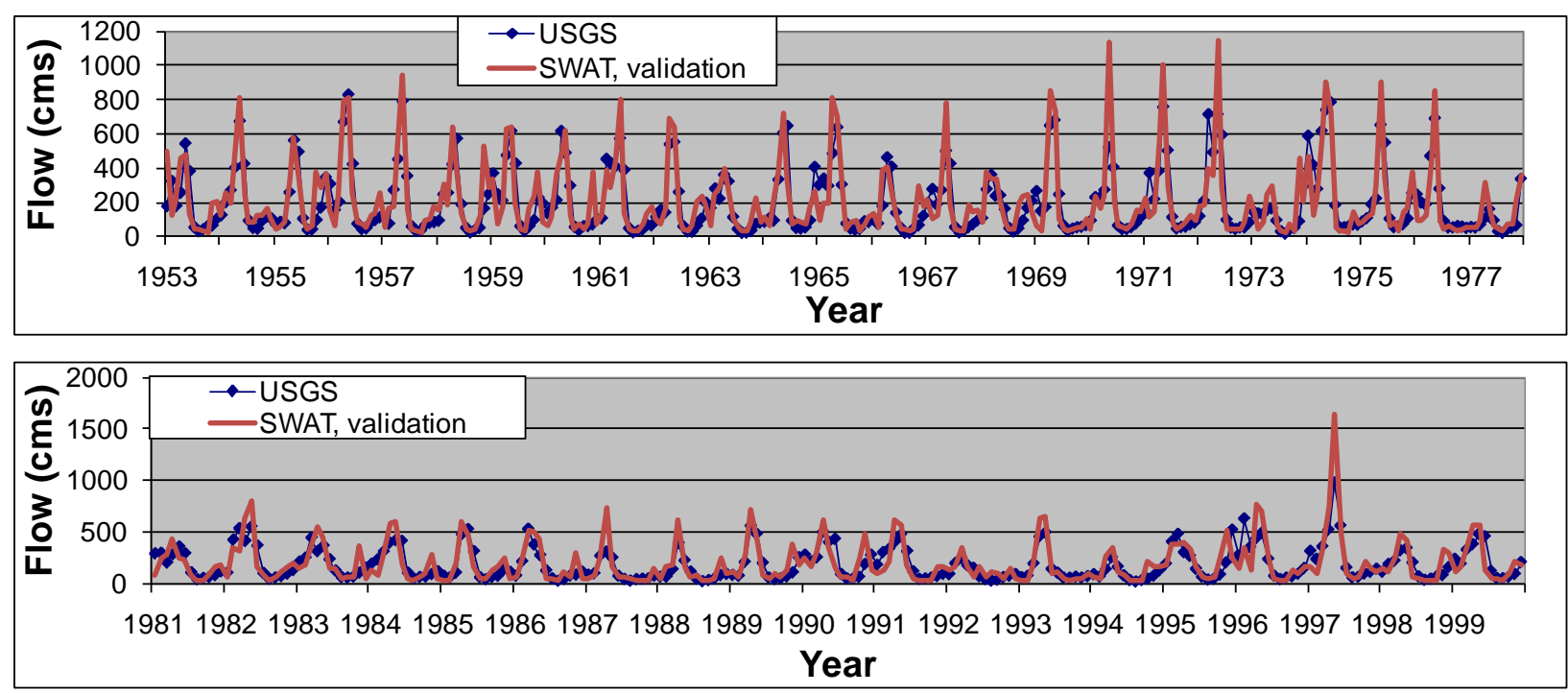

(b)

Figure 4 


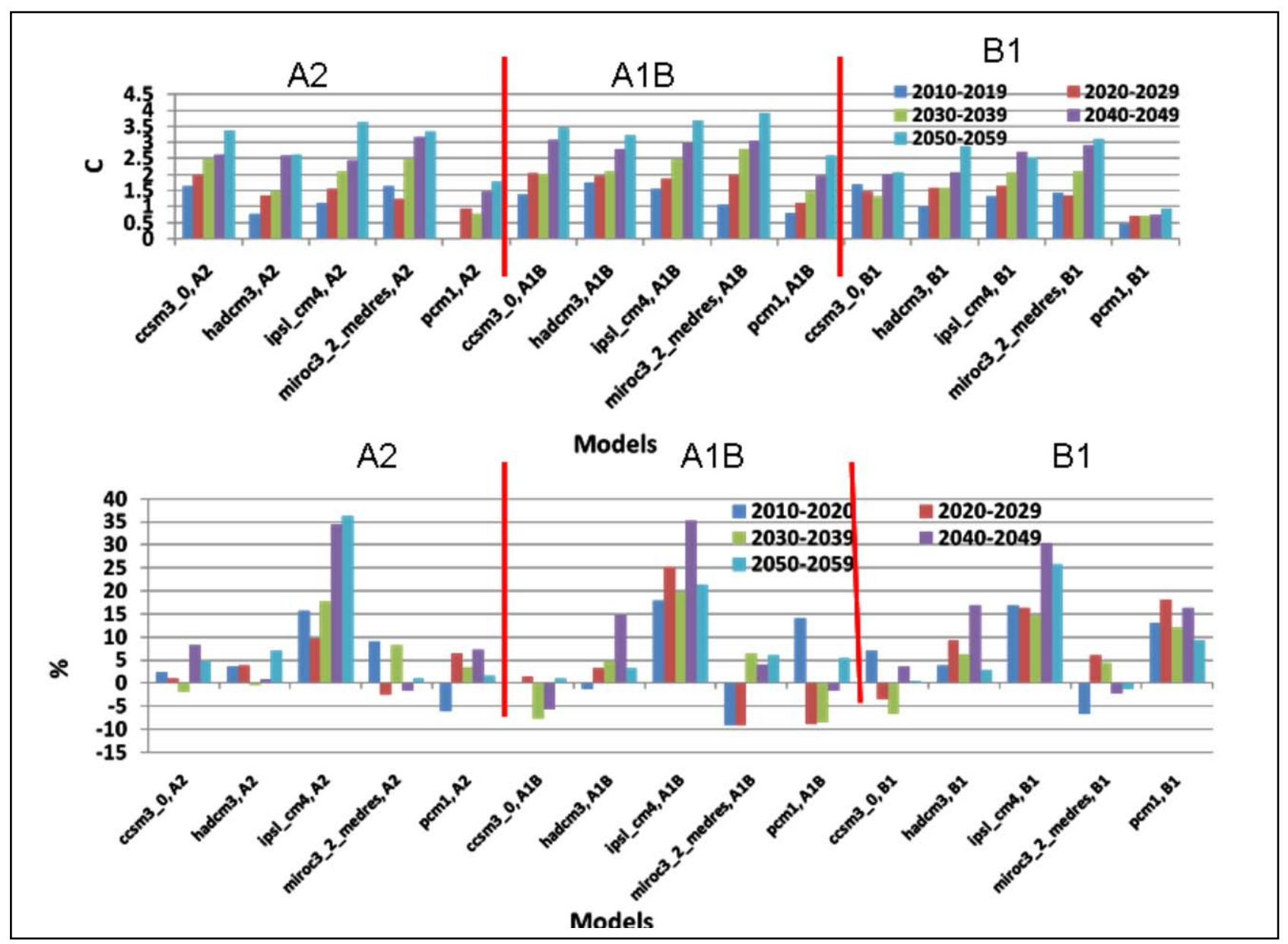

Figure 5 

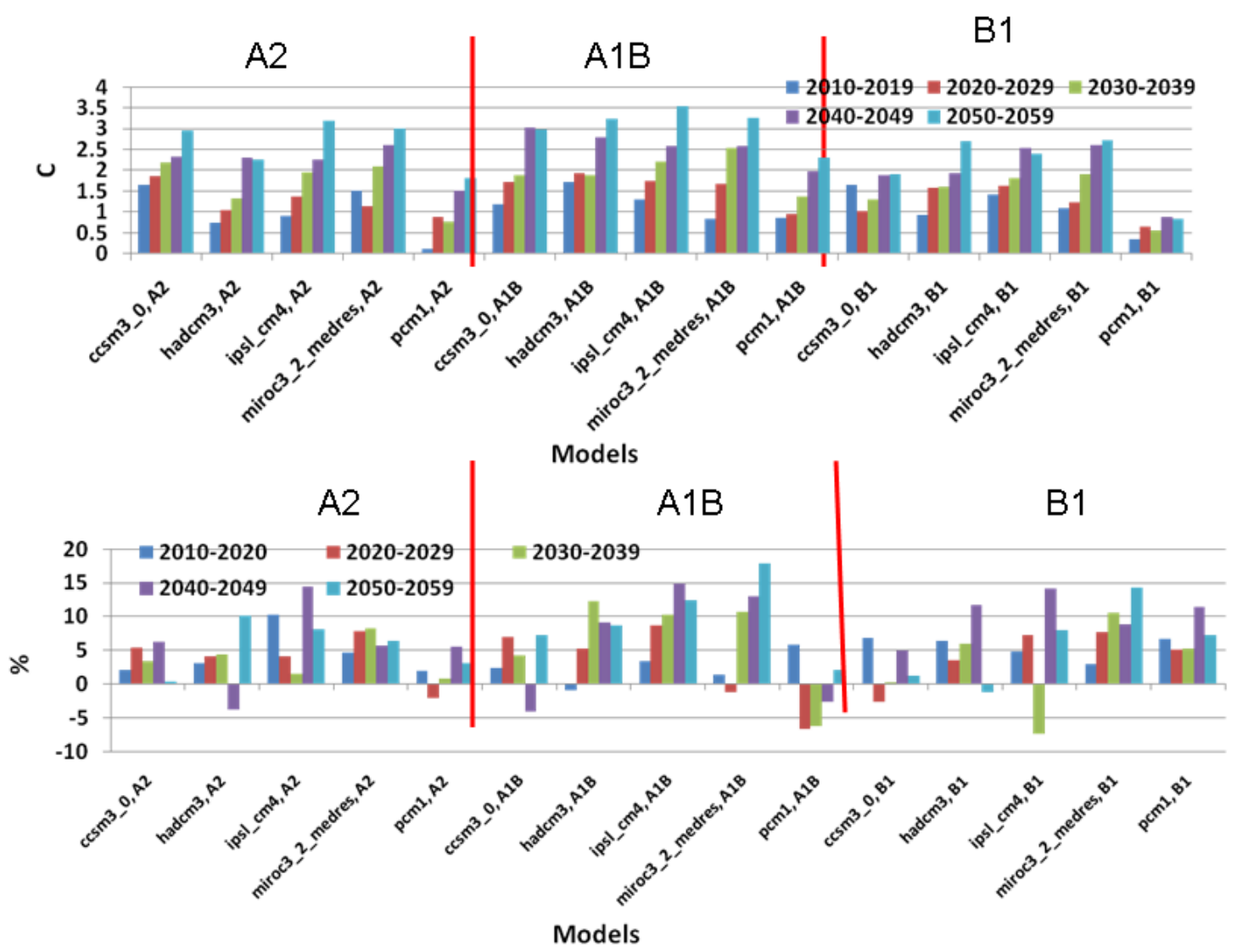

Figure 6 

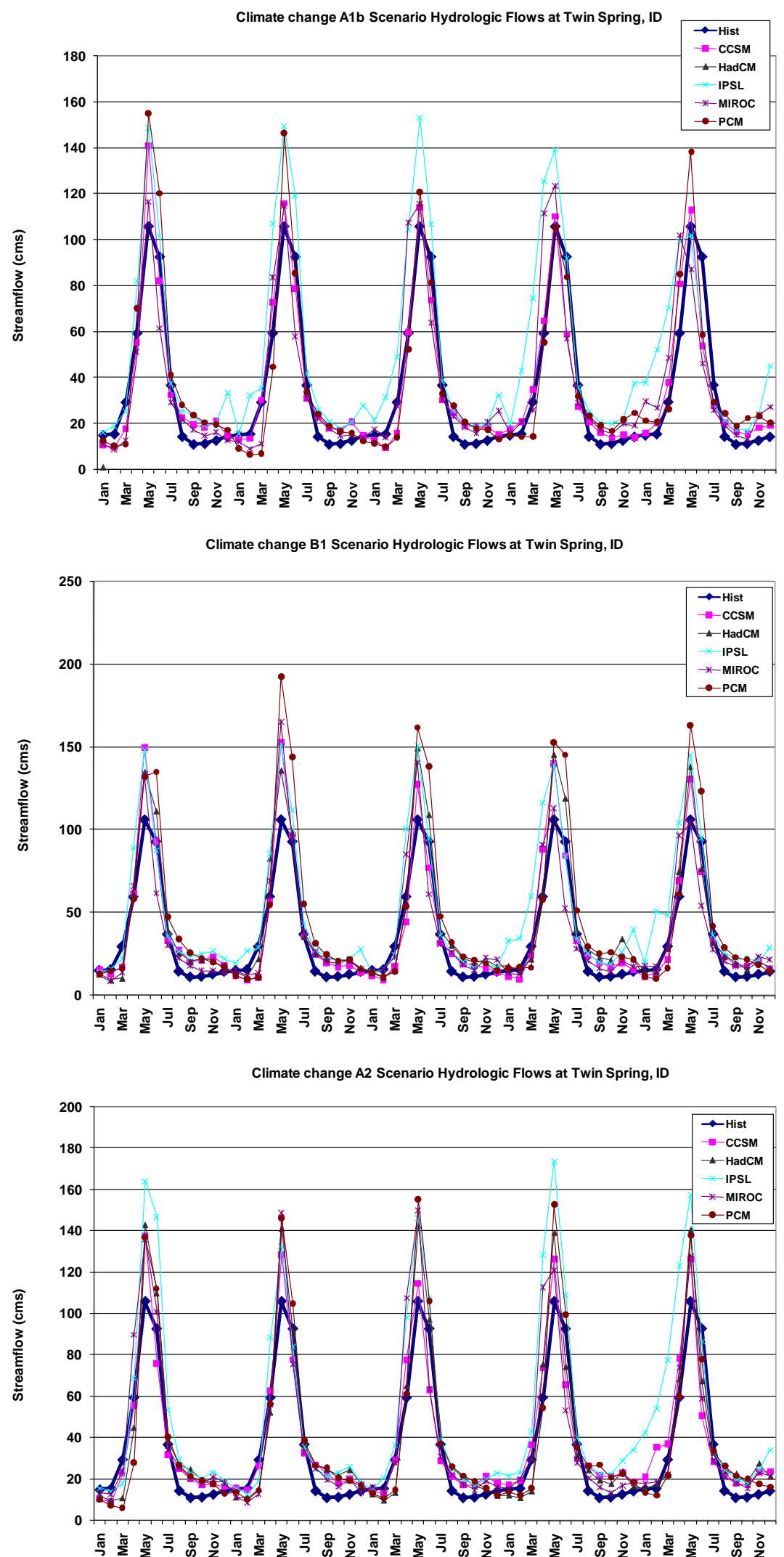

Figure 7 
This is an author-produced, peer-reviewed version of this article. The final, definitive version of this document can be found online at JAWRA: Journal of the American Water Resources Association, published by Wiley-Blackwell. Copyright restrictions may apply. The definitive version is available at www.blackwell-synergy.com. DOI: 10.1111/j.1752-1688.2011.00605.x
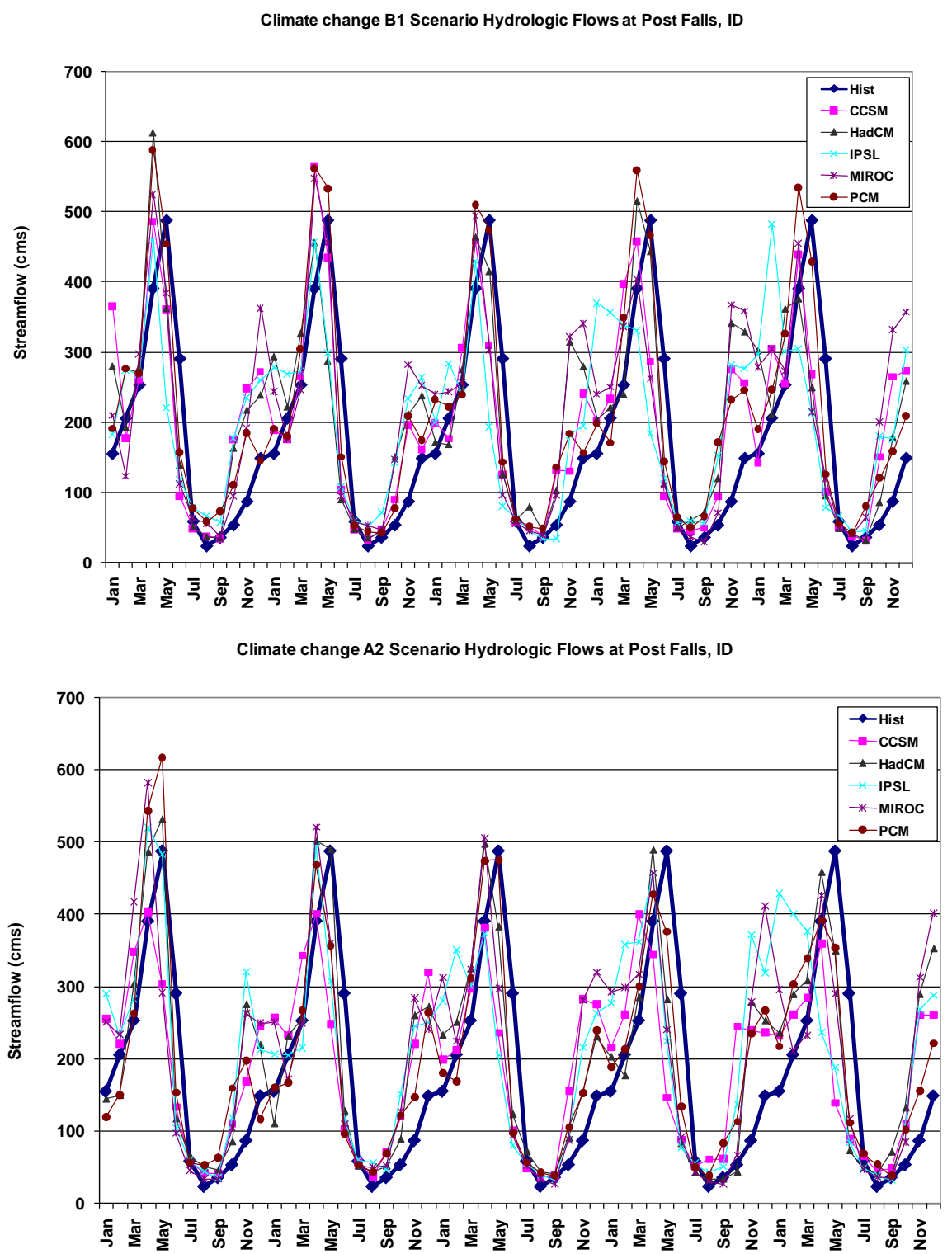

Figure 8 
This is an author-produced, peer-reviewed version of this article. The final, definitive version of this document can be found online at JAWRA: Journal of the American Water Resources Association, published by Wiley-Blackwell. Copyright restrictions may apply. The definitive version is available at www.blackwell-synergy.com. DOI: 10.1111/j.1752-1688.2011.00605.x
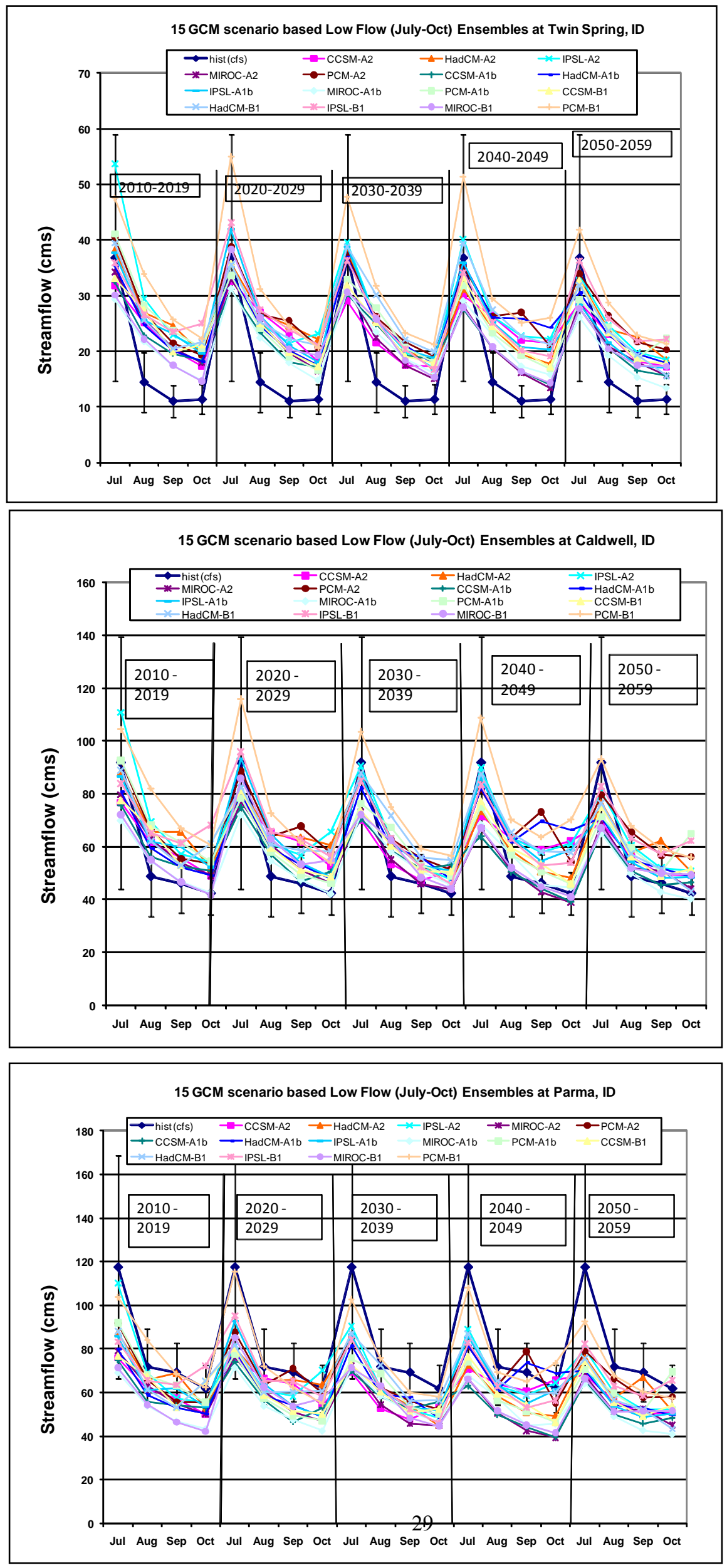

Figure 9 
This is an author-produced, peer-reviewed version of this article. The final, definitive version of this document can be found online at $J A W R A$ : Journal of the American Water Resources Association, published by Wiley-Blackwell. Copyright restrictions may apply. The definitive version is available at www.blackwell-synergy.com. DOI: 10.1111/j.1752-1688.2011.00605.x
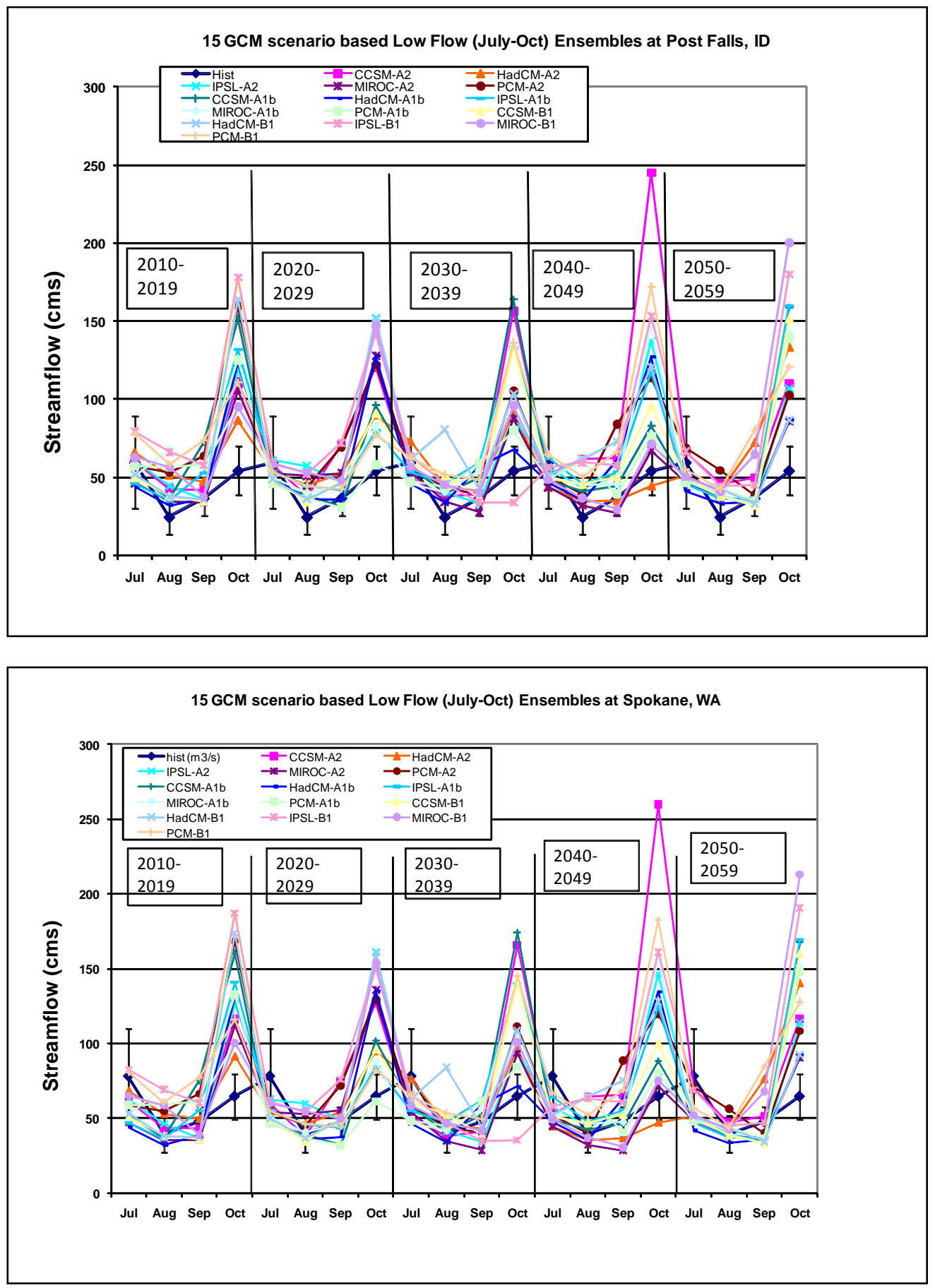

Figure 10 

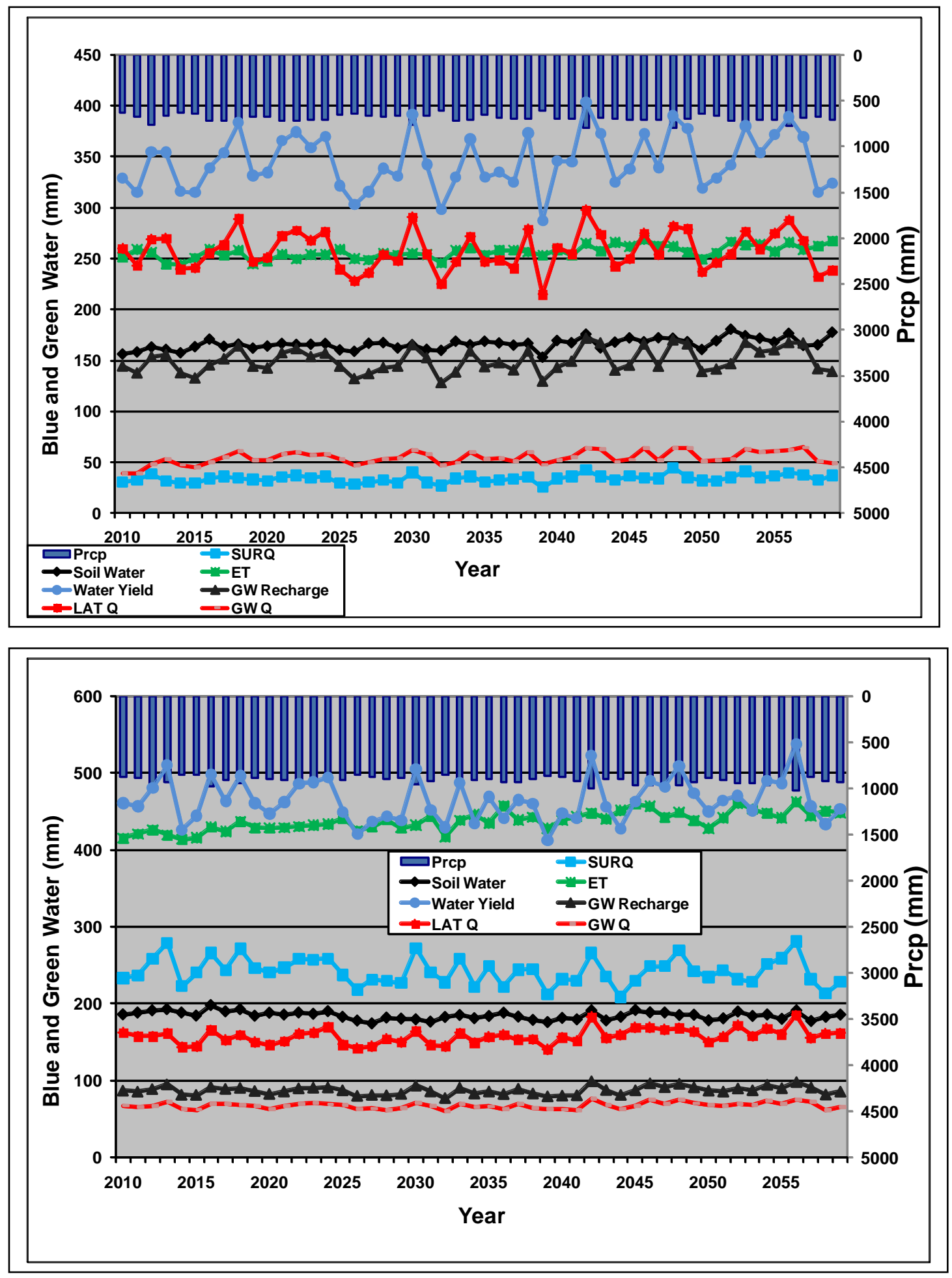

Figure 11 